UDC 339.727.22

DOI 10.33111/iep.2019.30.04_eng

\title{
Modern Offshoring Of Business In The Construct Of National Fiscal Security
}

\author{
ZORIANA LUTSYSHYN, \\ TETIANA Frolova, \\ NiNA YUZHANINA, \\ MYKOLA MAZUR, \\ DMytro Perebyinis ${ }^{1}$
}

\begin{abstract}
The paper investigates the economic content, nature and evolution of offshoring (formation of offshore system), identifies the main factors, mechanisms of functioning and features of structural changes in the offshore system, the determinants of development and formation of offshore centres, identifies the main directions and factors for the future of offshore centres/zones, territories (jurisdictions) in the world economy and investigates the volume and structure of capital outflow to offshore zones, jurisdictions; analyses the scheme of money laundering, identifies global trends in offshoring of financial services and investigates the progress and problems in financial services offshoring development in Ukraine.

According to the authors, the advantages of the offshore zones at the microeconomic level turn out to be shortcomings that compromise the stability of the global economic space. The prerequisites for the emergence and evolution of offshore business at each stage of development are investigated. The authors believe that the main purpose of the emergence and development of offshore jurisdictions is discrepancy between the desire of the state to fully control the financial situation in its territory and the reluctance of citizens to be controlled and give up their profits in the form of taxes. The modern network of the offshore financial centres is generated due to the significant mobility of financial assets in general, as well as the fact that the growth rate of the global financial market significantly exceeds the growth rate of the real economy. The world trends of offshoring of financial services are analysed and the reasons for their rapid growth are revealed. The analysis of the global financial flows shows
\end{abstract}

* This article was translated from its original in Ukrainian.

${ }^{1}$ Lutsyshyn Zoriana Orestivna - Doctor of Economics, Professor, Deputy Director of the Scientific and Methodical Centre of Educational Process Organization at Kyiv National Economic University named after Vadym Hetman. Honoured Worker of Education of Ukraine (2015). Sphere of scientific interests: financial globalization, international monetary and financial relations, financial mathematics in international business, geo-economics, conjuncture of the international financial market (including technical and fundamental analysis), international economic security, in particular financial. E-mail: zor_lu@ukr.net.

Frolova Tetiana Oleksandrivna - Doctor of Economics, Professor, Deputy Head at the Department of International Finance, Director at the Centre for Education Quality Management and Monitoring at Kyiv National Economic University named after Vadym Hetman. Sphere of scientific interests: financial globalization, corporate strategies of global investment business, finance of international corporations, international financial management, development and economic substantiation of international investment project decisions. E-mail: frol 7@ukr.net.

Yuzhanina Nina Petrivna - Chairman of the Verkhovna Rada of Ukraine Committee on Tax and Customs Policy. Honoured Economist of Ukraine. Sphere of scientific interests: taxes, financial security, international financial and fiscal security, offshores, de-offshorisation. E-mail: yuzhanina.nina@rada.gov.ua

Mazur Mykola Ihorovych - Master degree student at educational and professional training program «International Finance», major — «Finance, Banking and Insurance» at Kyiv National Economic University named after Vadym Hetman. Sphere of scientific interests: international monetary and financial relations, international trade, financial globalization, international economic security, incl. financial, geopolitics, geo-economics, offshore, de-offshore, international financial market conditions. E-mail: k.mazur1997@gmail.com.

Perebyinis Dmytro Serhiiovych - Master degree student at educational and professional training program «International Finance», major - «Finance, Banking and Insurance» at Kyiv National Economic University named after Vadym Hetman. Sphere of scientific interests: financial globalization, financial mathematics in international business, international economic security, geopolitics, international political activity, public administration. E-mail: dmytro.perebyinis@gmail.com.

IEP, № 30, (2019) pp. 70-111

(C) Zoriana Lutsyshyn, Tetiana Frolova, Nina Yuzhanina, Mykola Mazur, Dmytro Perebyinis, 2019 «All rights reserved» ISSN 1811-9832/2019/№ 1 (30) 
certain pattern of individual jurisdictions or entire zones being attracted to each other and creating a single complex global financial network. The evolution of global offshore wealth, its volume in tax havens are investigated.

The place of Ukraine in the global offshore network is determined. The article focuses on the offshore zones where the Ukrainian capital is fleeing and contains comparison between tax havens, free zones and other varieties of the offshore jurisdictions. The «Ukrainian» and the most common international schemes of withdrawing capital to the offshore zones are analysed. One of the issues raised is deoffshorization policy and fiscal security of Ukraine. The need of ensuring financial (including fiscal) security is becoming even more important in view of the economy globalization processes that are accompanied by imbalanced competition, market monopolization by individual states, and affect the global competitive environment. Threats to fiscal security and structural components of fiscal policy are investigated. The possible and most appropriate measures to improve the level of financial security of Ukraine and its component - tax policy - are outlined; the main directions and principles of deoffshorization; measures to reduce the outflow of capital from Ukraine are recommended.

KEYWORDS: offshore, offshoring, financial services market, offshore centres, offshore system, deoffshorization, financial centres, tax haven, fiscal oasis, securitization, tax asymmetries, fiscal security.

\section{Introduction}

We often talk about offshore and seldom comprehend the nature of this phenomenon. We also do not always understand the scale of this problem. Why did they emerge? What are the main «offshore» jurisdictions? Why exactly offshores attract business across the globe? What are the trends of recent years? How much wealth is hidden in offshores? How differs the participation of the Western and post-Soviet world in the offshores?

The world economy can be compared to an iceberg, the bulk of which remains concealed under water. The offshores (offshore centres, zones, tax havens, free zones) are exactly this underwater part of the iceberg. «More than half of world trade passes, at least on paper, through tax havens. More than half of all banking assets and a third of foreign direct investment by multinational corporations are routed offshore, writes British journalist Nicholas Shaxson in his book «Treasure Island. «Tax Havens and the Men Who Stole the World». ${ }^{2}$ According to him, 83 of the 100 largest American corporations and 99 of the 100 largest European have subsidiaries offshore.

The main element of «offshoring» is the unfavourable tax climate of the country, which can have many manifestations and be implemented at different levels and stages of capital movement. Choosing particular

\footnotetext{
${ }^{2}$ Offshoryi $v$ mire: 7 klyuchey dlya ponimaniya. [Electronic resource]. - Access mode: https://ru.hromadske.ua/posts/Offshory_V_Mire_7_Klyuchej_Dlya_Ponimaniya.
} 
tax climate format depends upon the current and target state of economy of the country involved or intending to be involved in international capital flow. Furthermore, the country tax climate affects not only the inflow of the international capital is attracted but also the outflow of national (domestic) capital. "Offshoring» is one of the components of globalization of the modern financial world. The very process of globalization in the context of internationalization means a huge redistribution of economic potential on a global scale, which is carried out through offshore.

\section{Offshore zones: concept, features and classification}

The development of modern business is organically associated with the globalization of the economy - the free movement of capital, the liberalization of foreign investment, create wide opportunities for the analysis of offshore entrepreneurship. The objectives pursued by the countries on whose territory an offshore zone is created may be different depending on the level of economic development of the country, the socio-economic environment, and other features of the countries.

The term comes from the English offshore or «located at a distance from the shore». ${ }^{3}$ These are financial centres / zones, territories that attract foreign capital through special tax and administrative benefits. Such countries (territories) and zones are called «financial paradise» for business.

Offshore zones are financial centres / territories, the main task of which is to create for entrepreneurs a favourable monetary and financial, fiscal regime, a high level of banking and commercial secrecy, loyalty to state regulation ${ }^{4}$.

According to D. Kose, «offshore zone is one of the types of free economic zones. They are referred to the service free-economic zones, the peculiarity of which is the creation of favourable monetary, financial and fiscal regimes for entrepreneurs, a high level of banking and commercial secrecy, loyalty to state regulation. In general, these are countries in which the participants of financial and credit operations are not residents of the state in which the transactions are concluded and executed. At the same time, participants enjoy a special legal and tax status, but an important characteristic is the prohibition of offshore companies operating in the territory of the country of registration. $\gg^{5}$

\footnotetext{
${ }^{3}$ Not to be confused with onshore, which is the complete opposite of offshore. Onshore does not offer any benefits. It is a company registered and operating in the territory of one country with favorable tax (fiscal) climate.

${ }^{4}$ Volkova Yu.A. Rozvytok ofshornykh tsentriv u systemi mizhnarodnoho biznesu / Yu.A. Volova // Formuvannia rynkovykh vidnosyn v Ukraini. — 2013. - No.1. — pp. 43-48. [In Ukrainian].

Kose D. D. Mistse pravovoho rezhymu opodatkuvannia ofshornoi terytorii u sferi rehuliuvannia ekonomichnykh vidnosyn / D. D. Kose // Chasopys Kyivskoho universytetu prava. — 2017. — No. 1. — pp. 18-23. [In Ukrainian].
} 
Offshore zones are also characterized as»a specific tool to stimulate investment and increase revenues to the budgets of depressed areas, the economic effect of which is based on the phenomenon of growth of state revenues due to the expansion of the tax base (using its special type of income derived from the implementation of foreign economic activity) and minimizing the tax burden». ${ }^{6}$

«Offshore zones (jurisdictions) are countries or separate territories of states where there are significant benefits in taxation, requirements for accounting and audit are reduced or there are no such requirements, customs and trade restrictions are partially or completely removed for certain types of companies owned by foreigners at the state level ${ }^{7}$. The conditions for granting benefits to such companies are non-residence, that is, they must be owned by foreigners and profits must be obtained outside the jurisdiction where they are registered.» We believe that the definition of H. McCann is somewhat incomplete, according to which the offshore zone is the whole or part of the territory of the country, where a preferential regime of operation of companies with offshore status is established and used, which conduct their activities outside the territory of registration and conduct operations with the property or money of non-residents ${ }^{8}$.

E. Shambost says that in the tax context, offshore is structure, which spending activities in any country not under fiscal control in the country. Basically, to avoid local taxes (or local regulation), offshore entities should not carry out local activities (onshore) or activities with residents of the country (registration).

So, the main features of offshore jurisdictions are:

1) payment of taxes. The vast majority of offshore jurisdictions provide for the payment of taxes. At the same time, they either do not pay income tax or pay it at a lower rate than in the country of the resident of the taxpayer;

2) financial secrecy. Some level of financial secrecy exists both in offshore jurisdictions and in other countries. However, the vast majority of countries do not protect financial secrecy in cases of investigation by law enforcement agencies of foreign countries. The main difference

\footnotetext{
${ }^{6}$ Apel A. Obnalichivanie y offshornyiy biznes v shemah / A. Apel, V. Gunko, Y. Sokolov. — Spb: Piter. — 2016. - p.15. [In Russian].

McCann H. Offshore Finance. Cambridge: Cambridge University Press, 2006. Reportof the Working Groupon Offshore Centers: Financial Stability Board, 2014 [Electronic resource]. — Access mode: http://www.financialstabilityboard.org/; Verhun V. A. Hlobalnyi riven rehuliuvannia praktyky stvorennia i diialnosti ofshornykh zon i terytorii / Verhun V. A., Stupnytskyi O. I. // Problemyi razvitiya vneshneekonomicheskih svyazey i privlecheniya inostrannyih investitsiy: regionalnyiy aspekt : sb. nauch. Tr. / red. Yu. V. Makohon [y dr.]. - Donetsk : DNU, 2013. - p. 44. [In Ukrainian]

${ }^{8}$ McCann H. Offshore Finance. Cambridge: Cambridge University Press, 2006. Reportof the Working Groupon Offshore Centers: Financial Stability Board, 2014 [Electronic resource]. - Access mode: http://www.financialstabilityboard.org/
} 
between offshore jurisdictions is quite strict rules for the protection of financial secrecy, including banking and commercial;

3) currency control. Offshore jurisdictions typically use a dualcurrency control. Such control is applied differently for residents and non-residents, as well as for national and foreign currencies. Residents are subject to currency control and non-residents are not. In this case, non-residents are subject to normal control in the case of the use of local currency.

An offshore company is a way of doing business with significant savings on tax expenses. Not only the owner of a large business but also an ordinary freelancer can open a company in the offshore zone. Various schemes of tax payments and a wide geography of offshore jurisdictions provide great opportunities for effective conduct of business. To register or re-register an offshore company, you can choose any part of the world. It is important only to know the features of offshore zones of different types ${ }^{9}$.

There are more than fifty offshore zones in the world. According to rough estimates, about ten $(9.8 \%$ ) percent of all funds on the planet are concentrated there. According to some estimates, the total amount of wealth kept in the offshore zones can be as high as USD 32 trillion, which is more than the US and Japanese GDP combined ${ }^{10}$.

The advantages of using offshore zones for businesses include: the possibility of opening several offshore companies during the privatization of an enterprise to keep confidential the identity the enterprise's owner and thus being able to obtain a controlling stake, no requirement of submitting accounting reports, the extremely requirements to the authorized capital and the possibility of acquiring the status of IBC (International Business Company), getting profit (capital) in hard currency, getting access to reliable banks in a stable country, an effective and inexpensive banking system.

Advantages of using offshore zones at the microeconomic level, at the same time, are disadvantages and pose a threat to the stability of the global economic space. Among the main disadvantages are the following ${ }^{11}$ : tax evasion, unfair tax competition, support for the shadow economy, the impact on the social situation in the country, the creation of conditions for the outflow of capital, the creation of elements of

\footnotetext{
${ }^{9}$ Ofshorni zony: vydy ta osoblyvosti. // Hazeta Vikna. [Electronic resource]. - Access mode: //http://vikna.if.ua/cikavo/68688/view. [In Ukrainian].

${ }^{10}$ Ofshor - chto eto takoe prostyim yazyikom? Razbiraemsya v prichinah skandala [Electronic resourcel. Access mode: https://sputnik-georgia.ru/amp/spravka/20160406/231003155/Ofshor-chto-jeto-takoe-prostymjazykom-Razbiraemsja-v-prichinah-skandala.html [In Russian].

Skhemy ta perspektyvy vyvodu kapitaliv do ofshornykh zon. // Informatsiino-analitychnyi portal Ukrainskoho ahentstva finansovoho rozvytku. - 2015. [Electronic resource]. - Access mode: http://www.ufin.com.ua/. [In Ukrainian].
} 
instability in the world economy and Finance in connection with the possibility of accumulation in offshore zones of large amounts of capital, especially speculative, obtaining outside competitive advantages by those companies that use offshore.

Offshore zones are divided into two groups: with full and tax offshoring.

Full offshoring is an exemption from any reporting, and payment by entrepreneurs of fairly low interest in the form of taxes or a small fixed amount. In some areas, the entrepreneur may receive a full tax exemption (Dominica, Cyprus, British Virgin Islands, Belize, Seychelles, Federation of St. Kitts and Nevis).

Tax offshore area is reduced rates, but without the release of the companies from accounting and reporting. This group includes Hong Kong, Scotland, Panama.

«Tax havens» (Free zone) - offshore companies located inside (for example, the UAE).

Investment attractiveness of various offshore zones depends on the conditions of registration and taxation. In addition, the Forum of financial stability of developed countries, created by the former President of the Bundesbank ${ }^{12}$, determined the rating of offshore zones in terms of their reliability:

- the first group includes Switzerland, Luxembourg, Dublin, Hong Kong, Singapore, Guernsey, Maine and Jersey;

- the second reliability group includes Labuan, Monaco, Malta, Andorra, Cyprus, Gibraltar, Bermuda, Macau, Barbados;

- the third group includes Cyprus, Liechtenstein, Antigua, Lebanon, Panama, Anguilla, Cayman Islands, British and Virgin Islands, Belize, Aruba, Cook Island, Bahamas. It is worthwhile to note that the factor of favourable investment climate of the 2nd and 3rd group countries plays an important role in the choice of investment objects by Ukrainian business entities ${ }^{13}$.

The features of offshore zones and the principles of doing business in them according to classification criteria are presented in table 1.

Thus, an offshore zone is a country or part of the territory of the country where tax and other benefits are provided to non-residents, a special regime of currency control is introduced and the right of financial secrecy is guaranteed. In addition, there are certain types of offshore financial centres, among which there are so-called paper centres that store documentation, and carry out banking operations in small

\footnotetext{
${ }_{13}^{12}$ Central Bank of Germany

${ }_{13}$ Moskalenko, N. V. Problemy, zumovleni funktsionuvanniam ofshornykh yurysdyktsii, ta shliakhy yikh rozviazannia [Tekst] / Moskalenko N. V. // Aktualni problemy ekonomiky. — 2009. — No. 10. — pp. 117-121. [In Ukrainian].
} 
amounts or not at all, and functional centres that carry out deposit operations and provide loans.

Table 1

FEATURES OF OFFSHORE ZONES ACCORDING TO CLASSIFICATION CRITERIA

\begin{tabular}{|c|c|}
\hline Group & Characteristics and principles of business \\
\hline $\begin{array}{l}\text { Offshores of the } \\
\text { first group: } \\
\text { Bahamas, } \\
\text { Panama, BVI - } \\
\text { British Virgin } \\
\text { Islands }\end{array}$ & $\begin{array}{l}\text { Registration of offshore companies in these zones is an excellent } \\
\text { opportunity to save your money from excessive payment of taxes, as well } \\
\text { as to minimize the amount of taxes and fees for operations in the currency } \\
\text { and stock markets. The cost of creation includes, as a rule, the minimum } \\
\text { service that is necessary to maintain the secretarial offices, which, in fact, } \\
\text { are engaged in paper cases. } \\
\text { Offshore opens quickly enough, with an average of about two weeks. High } \\
\text { anonymity allows you to achieve excellent results in terms of secrecy, but } \\
\text { this negatively affects the trust of partners. Reputable organizations are } \\
\text { not very inclined to deal with such structures. }\end{array}$ \\
\hline $\begin{array}{l}\text { Offshores of the } \\
\text { second group: } \\
\text { Seychelles, } \\
\text { Ireland, } \\
\text { Gibraltar }\end{array}$ & $\begin{array}{l}\text { Provides its owners with much more opportunities to do business with } \\
\text { reputable customers, as confirms a greater level of loyalty. Regardless of } \\
\text { whether or not reporting is required in a particular country of the offshore } \\
\text { zone (there are countries with mandatory reporting organizations, and } \\
\text { without it) information about the entrepreneurs of the company is subject } \\
\text { to registration. } \\
\text { Offshore zones of the second group enjoy increased confidence, so allow } \\
\text { the availability of reliable information about the management of the } \\
\text { company (not only nominal service in the form of a secretarial bureau, as } \\
\text { in offshore zones of the first group). }\end{array}$ \\
\hline $\begin{array}{l}\text { Offshores of the } \\
\text { third group: } \\
\text { Cyprus, USA, } \\
\text { Great Britain }\end{array}$ & $\begin{array}{l}\text { In fact, these territories are only called offshore. USA, for example, } \\
\text { provides an opportunity for non-residents not to pay Federal taxes on } \\
\text { activities not related to operations within the country, in violation of the } \\
\text { status of «offshore» is lost. England makes it possible to build an offshore } \\
\text { chain. A popular scheme is the opening of a company in the Great } \\
\text { Britain: }{ }^{4} \text { an office opens in England, and a branch through which } \\
\text { operations are conducted in Cyprus. Cyprus is a very attractive place to } \\
\text { open offshore, due to the lack of bilateral taxation of companies. }\end{array}$ \\
\hline
\end{tabular}

Source: Developed by the authors according to Cassard $M$. The Role of Offshore centres in International Financial Intermediation / M. Cassard / IMF Working paper. - 2014. No. 107. - pp. 22-32.

There are three types of offshore banking (financial) centres:

The first type - the New York model - provides for special formally established agreements with authoritative financial centres such as New York, Tokyo, Singapore. These markets set up special accounts separately from the domestic ones and these accounts are free from restrictions that apply to the domestic financial market (e.g. reserve

\footnotetext{
${ }^{14}$ The level of taxation is quite high, but at a small profit, it is either below the nominal one by $30 \%$, or as high as 0 in an organization with a profit of up to $£ 10,000$.
} 
requirements). There is corporate taxation, local stamp duty (in the Tokyo market), taxation of business securities (allowed in Singapore), and not available in the markets of New York and Tokyo.

The second type is the London model. In London, Hong Kong, financial transactions are free from restrictions, regardless of whether residents or non-residents are market participants. In these cities, the offshore market is just offshore transactions between non-residents, because the internal and external agreements are combined. In the offshore markets of this model there is corporate taxation and taxation of business securities is allowed.

The third type is «tax haven». This type of offshore markets includes the markets of the Bahamas and Cayman Islands. Transactions are concluded by non-residents and are not taxed at all, there is no corporate taxation and taxation of business securities, but there are registration fees and license fees in these markets ${ }^{15}$.

\section{The background and evolution of the offshore business}

The main reason for the formation of a modern network of offshore financial centres is the significant mobility of financial assets in general, as well as the fact that the growth rate of the global financial market is significantly ahead of the growth rate of the real economy.

An obvious impetus for the growth of the rate of financial assets flow in the world financial market in the late 1970s of the last century was the approval of the conditions for the functioning of the Jamaican monetary system. The liberalization of the foreign exchange market, defined as a priority of the Jamaican monetary system, in turn, acted as a catalyst for the development of infrastructure and technology in all sectors of the financial market.

The increase in the profitability of operations with financial assets and the openness of borders to capital led to the active involvement of institutional units in the processes of financial communication, the purpose of which was to reduce the share of taxes in the structure of income from operations with financial assets.

The modern hierarchy of these centres has been formed during the last decades under the influence of both purely economic factors and changes in the domestic policy of developed countries. Offshore business is constantly changing and becoming more complex, adapting to new requirements and conditions caused by changes in the legal framework. As a result, the use of offshore zones is becoming more and more difficult.

\footnotetext{
${ }^{15}$ Mizhnarodni finansy: Navch. posib. / O. M. Mozghovyi, T. Ye. Obolenska, T. V. Musiiets ta in., Za zah. red. d-ra ekon. nauk, prof. O. M. Mozghovoho - K.: KNEU, 2005. - pp. 89-90. [In Ukrainian].
} 
The main purpose of the emergence and development of offshore jurisdictions is inconsistency between the desire of the state to fully control the financial situation in its territory and the reluctance of citizens to be controlled and give their profits in the form of taxes.

The history of the origin of the prototypes of modern offshore zones reaches the first Millennium $\mathrm{BC}$, in a period of prosperity of the Phoenicians, and continues to this day. In one form or another, throughout the history of mankind, various countries and peoples have been trying to intensify international trade and attract foreign capital by creating special, tax-friendly economic conditions in some of their territories. (table 2).

Table 2

EVOLUTION OF OFFSHORE ZONES

\begin{tabular}{|c|c|c|}
\hline $\begin{array}{l}\text { Period of } \\
\text { occurrence }\end{array}$ & Country & Features of offshore zones \\
\hline $\begin{array}{l}\text { millennium } \\
\text { BC }\end{array}$ & $\begin{array}{l}\text { Small Islands } \\
\text { near Athens in } \\
\text { the Aegean } \\
\text { Sea }\end{array}$ & $\begin{array}{l}\text { Athens imposed a } 2 \% \text { export and import tax, making the } \\
\text { small neighbouring Islands a haven for duty-free and tax-free } \\
\text { trade and places of accumulation of smuggled goods going to } \\
\text { Athens without paying taxes. }\end{array}$ \\
\hline $\begin{array}{l}\text { XV } \\
\text { century }\end{array}$ & Flanders & $\begin{array}{l}\text { Flanders was a thriving international commercial centre with } \\
\text { few restrictions or taxes on local and foreign goods. As a } \\
\text { result, English merchants preferred to sell their wool in } \\
\text { Flanders rather than in England, where they would have to } \\
\text { pay high taxes and duties. }\end{array}$ \\
\hline $\begin{array}{l}\text { XVШ-XIX } \\
\text { century }\end{array}$ & $\begin{array}{l}\text { USA } \\
\text { (New Jersey, } \\
\text { Delaware) }\end{array}$ & $\begin{array}{l}\text { The grounds for a liberal business regime, including low } \\
\text { taxation for companies that would operate within the state. } \\
\text { For the possibility of incorporation, the business paid a small } \\
\text { franchise tax. }\end{array}$ \\
\hline $\begin{array}{l}\text { XIX } \\
\text { century }\end{array}$ & Great Britain & $\begin{array}{l}\text { Companies that were registered in the Great Britain, which } \\
\text { are managed outside of it, did not have to pay taxes to the } \\
\text { Treasury of the state. }\end{array}$ \\
\hline $\begin{array}{l}\text { the end of } \\
\text { XIX } \\
\text { century }\end{array}$ & Switzerland & $\begin{array}{l}\text { It was here that one of the elements of the offshore business } \\
\text { arose - banking secrecy, anonymous numbered Bank accounts } \\
\text { were invented. They created the Institute of front Directors } \\
\text { and owners of the company. }\end{array}$ \\
\hline 1965 & Bahamas & $\begin{array}{l}\text { There was the first Bank offshore. Special legislation has been } \\
\text { developed to allow Bahamian banks to serve non-residents in } \\
\text { foreign currencies. }\end{array}$ \\
\hline $\begin{array}{l}\text { 1970s: } \\
\text { XX } \\
\text { century }\end{array}$ & $\begin{array}{l}\text { Cyprus, } \\
\text { Ireland, } \\
\text { Maine, } \\
\text { Gibraltar }\end{array}$ & $\begin{array}{l}\text { Offshore jurisdictions challenged the national isolation of } \\
\text { financial systems, created conditions for accelerating the } \\
\text { liberalization of financial markets and the rapid growth of a } \\
\text { variety of cross-border financial flows. Within countries, } \\
\text { deregulation of banking activities was rapidly disappearing, } \\
\text { barriers to international financial transfers were removed and } \\
\text { stock markets were opening up for non-residents, and there } \\
\text { was a rapid transition from fixed to «floating exchange rates». }\end{array}$ \\
\hline
\end{tabular}


End of the table 2

\begin{tabular}{|c|c|c|}
\hline $\begin{array}{l}\text { Period of } \\
\text { occurrence }\end{array}$ & Country & Features of offshore zones \\
\hline $\begin{array}{l}\text { the end of } \\
\text { XX } \\
\text { century }\end{array}$ & USA & $\begin{array}{l}\text { Restrictions on the payment of interest on Deposit-and-loan } \\
\text { transactions were lifted and interest on demand deposits was } \\
\text { introduced, a } 30 \% \text { tax on income on bonds issued in the } \\
\text { United States owned by non-residents was abolished; a system } \\
\text { of international banking zones with preferential treatment was } \\
\text { created, where foreign banks were also exempted from } \\
\text { compliance with the requirements for the creation of } \\
\text { mandatory reserves in the United States. After the adoption of } \\
\text { the international banking act in 1978, foreign banks were } \\
\text { granted the right to open so-called Edge corporations in the } \\
\text { United States (for United States banks, such corporations } \\
\text { could be created in accordance with the Edge Act since } \\
\text { 1919). These corporations have the right to make mutual } \\
\text { investments in foreign banks and financial companies, as well } \\
\text { as companies providing financing services and banking } \\
\text { services; Glass-Steagall Act was abolished, which introduced } \\
\text { strict regulation of lending processes and the opening of Bank } \\
\text { branches. }\end{array}$ \\
\hline $\begin{array}{l}\text { XXI } \\
\text { century }\end{array}$ & $\begin{array}{l}\text { (regardless of } \\
\text { the country of } \\
\text { operation) }\end{array}$ & $\begin{array}{l}\text { We can distinguish the following main features of modern } \\
\text { offshore banking centres: liberalized currency and credit } \\
\text { legislation, transactions mainly with foreign currency for the } \\
\text { country, deposited capital is not without movement } \\
\text { (intended for investment of high-income industries with low } \\
\text { taxation abroad), a guarantee of financial and banking } \\
\text { secrecy, the absence of currency restrictions, convenient tax } \\
\text { system etc. }\end{array}$ \\
\hline
\end{tabular}

Source: developed by the authors according to Baul O., Sachuk A. Features of the evolution of offshore zones in a globalized economy. / Baul O., Sachuk. A. Economist No. 1. - 2012. No. 1. - P. 17.

For the first time the concept of «offshore» came into practice in the middle of the twentieth century - one nimble firm «left» from the US tax office, registered in another country - with lower taxes. But in fact - it all started much earlier. Even the ancient Greeks avoided paying taxes, making a detour around Athens and transported goods to numerous dutyfree Islands. In Ancient Greece, as in our days, the authorities levied taxes on merchants. Athenians took $2 \%$ of the value of all goods entering the city or in transit: port charges from ships, taxes from foreigners, slaves and women of easy virtue. Those who wanted to trade in local markets were also generous with a tidy sum. The final costs were so great that trade with Athens, a large metropolis, for foreigners has become unprofitable. To avoid paying taxes Greek and Phoenician merchants avoided the 
30-kilometer zone around the city. They set up their own free warehouses to store goods on tiny Islands, and then smuggled them.

The island of Rhodes became the first major offshore company in history. After a time, wanting to get rich, the government introduced a two-percent tax on exports and imports. The result was the opposite: the city lost most of its trade. Enterprising merchants moved to another place - on the island of Delos.

The economy of medieval Europe is closely connected with the merchants of Venice, Genoa, Livorno, Trieste, the Hanseatic League. Port cities on the Mediterranean and Adriatic coasts, the Baltic and the North seas developed rapidly, thanks to the liberal trade policy of local authorities. One of the most significant examples is the Hansa. It is the Union of the guilds of merchants in XII-XVII centuries, which is jointly led by business and asked for preferences from the European monarchs. Almost three hundred cities have created favourable conditions for «their» merchants and from this rich. Offices of the Hanseatic League were also in Novgorod, Kaliningrad, Tallinn, Riga.

Another way of successful trade is participation in fairs. This was a landmark event for medieval society, because even foreign merchants did not pay duties. And in the XV century in Flanders was a very low trade restrictions and taxes, that the English merchants were more profitable to carry and sell the fur here, not in England. Large Maritime States in the XVI-XVIII centuries encouraged Maritime piracy, calling it a privateer. Filibusters used to undermine trade and economy rivals. But one day the situation got out of control. Pirates unbelted and obsessed with profit, began to «work» for themselves. Pirate and smuggler bases in Panama, the Cayman Islands and the Virgin Islands were used to store the loot. Here, in the absence of control, numerous shady transactions were carried out.

In the era of New time has been the development of Porto-Franco. These are seaports, where the laws of duty-free trade, import and export of goods were in force. In the Russian Empire, the cities of Porto Franco were Odessa, Batumi, Vladivostok, Feodosia, the mouth of the $\mathrm{Ob}$ and Yenisei. With the introduction of duty-free trade Odessa almost caught up with St. Petersburg in turnover for five years. Such cities quickly became rich, but then there were shortcomings of the system. Cheap imports destroyed local industry, increased corruption, smuggling, the shadow economy.

Many British colonies also received preferential taxation, which contributed to their development. In Europe, according to the same scheme, appeared offshore companies in Luxembourg, Liechtenstein, 
Switzerland. It was in the latter that the concept of financial secrecy was developed, when the name of the owner of the monetary contribution was carefully hidden. Due to this, a small country started to receive money from all over the world. ${ }^{16}$

Regarding the use of offshore zones by businessmen of Ukraine, they first got the opportunity to open offshore companies in 1991. With the independence of Ukraine. «In April 1991, the Swiss company Riggs Walmet Group announced that it was entering the Ukrainian market with an offer to organize companies. They offered not only assistance in setting up tax-free companies, but also support for their activities making annual contributions to the home country budget, providing secretarial services for processing irregular mail, organizing annual meetings of shareholders, drawing up balance sheets etc. By international standards, the cost of services was quite high: USD 4,800. for registration and USD 1,100 annually for the support.» ${ }^{17}$

In recent years, there have been many new offshore jurisdictions, the main purpose of which is to serve the capital received in the countries of the Commonwealth of Independent States and the Asia-Pacific region. These offshore jurisdictions include Samoa, Cook Islands, Cyprus, Niue. Banking secrecy as one of the elements of the offshore business was developed in Switzerland, whose banks offered a guarantee of secrecy of their deposits during the French revolution.

The scientific and technological revolution, which is of great importance in financial and economic activities of offshore companies, has become a driving force for the positive development of offshore jurisdictions and their further use. It would be very difficult to maintain the functioning of many offshore jurisdictions at the proper level without scientific and technical achievements, which consist in the development of advanced information technologies and means of communication. The situation when an offshore company is registered in one country, operates in the second, a bank account is opened in the third, and the owner of an offshore company lives in the fourth is typical for offshore relations.

\section{Offshoring of the world economy}

The analysis of the global financial flows shows an interesting pattern of individual jurisdictions or entire zones being attracted to each

\footnotetext{
${ }^{16}$ Iz istorii «ofshorov» ili kakaya byila tenevaya ekonomika ranshe. [Electronic resource]. — Access mode: https://homsk.com/martin/iz-istorii-ofshorov-ili-kakaya-byla-tenevaya-ekonomika-ranshe [In Russian].

Cherep A. V. Osoblyvosti rozvytku ofshornoho biznesu v Ukraini // Ekonomika ta derzhava. — 2014. No. 6. - C. 21-30. [In Ukrainian].
} 
other and creating a single complex global financial network. Fig. 1 illustrates bilateral financial relations between 34 territories having had the largest cross-border flows in 2012(USD 81.6 trillion).

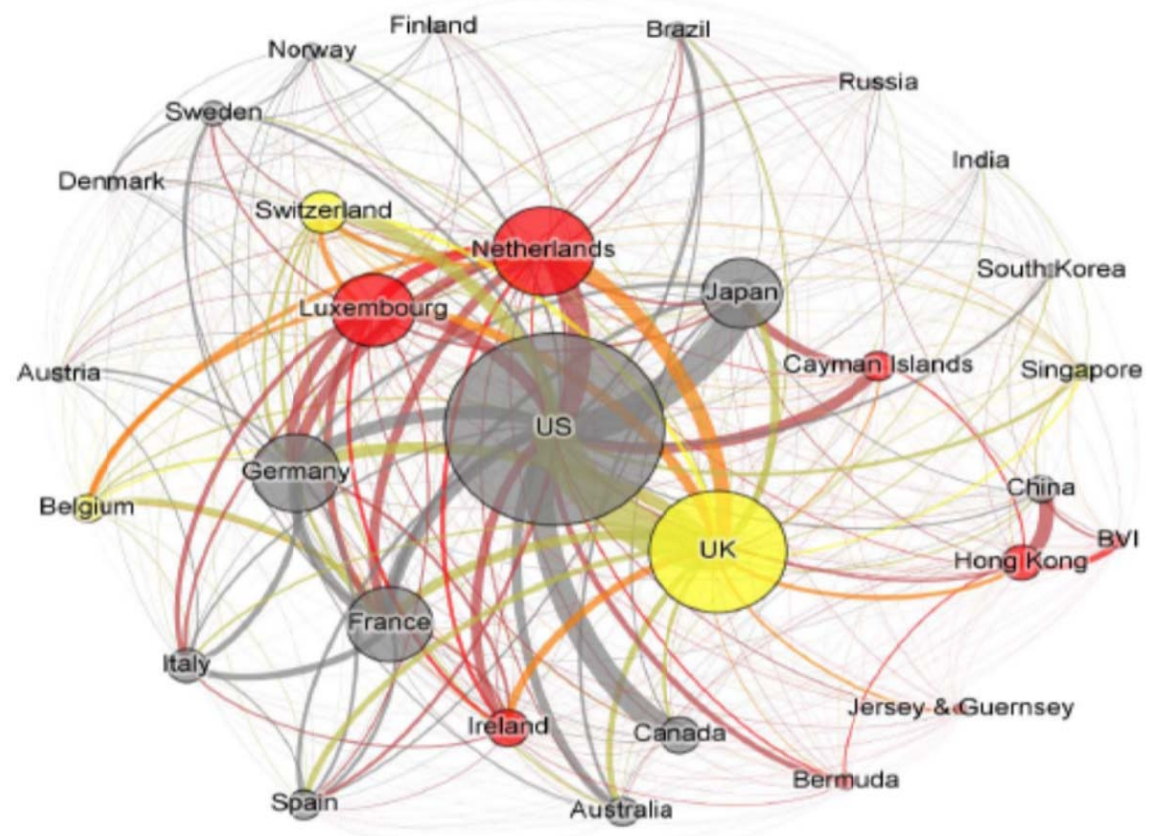

Fig. 1 Cross-Border financial flows

Source: Quoted by Offshore financial centres in the global capital movement. Lutsyshyn Z. O. Mekhtiiev Y. O. international Economics policy. - 2017. - 2 (27) [Electronic resource.] -Access mode: http://iepjournal.com/journals/27/2018_3_Lutsyshyn_Mekhtiiev.pdf, p. 76

Size of the circles indicates the volume of cross-border financial flows, and the colour - the offshorization level (grey - jurisdictions not recognized as offshore financial centres (OFCs), yellow - potential OFCs, red - obvious OFCs). The largest bilateral relations in total amounting to USD 4.7 trillion exist between the United States and Great Britain, an important role also belongs to the Netherlands, Luxembourg, Ireland, Hong Kong, the Cayman Islands, the Islands of Bermuda and British Virgin Islands. ${ }^{18}$

${ }^{18}$ Lutsyshyn Z. O., Mekhtiiev Ye. O. Ofshorni finansovi tsentry u hlobalnomu rusi kapitaliv. / Lutsyshyn Z. O., Mekhtiiev Ye. O. // Mizhnarodna ekonomika polityka. - 2017. - 2 (27). - pp.62-94. [Electronic resource]. Access mode: http://iepjournal.com/journals/27/2018_3_Lutsyshyn_Mekhtiiev.pdf [In Ukrainian]. 
Table 3

THE RATING OF FINANCIAL centres IN COUNTRIES ON THE INDEX GCFI IN 2017

\begin{tabular}{|c|c|c|c|c|}
\hline Place & Change & Financial centre & Indicator & Change \\
\hline 1 & $\boldsymbol{\Delta} 1$ & New York & 788 & $\nabla 5$ \\
\hline 2 & $\boldsymbol{\nabla} 1$ & London & 786 & $\nabla 8$ \\
\hline 3 & - & Hong Kong & 783 & $\Delta 2$ \\
\hline 4 & - & Singapore & 769 & $\Delta 4$ \\
\hline 5 & $\Delta 1$ & Shanghai & 766 & $\Delta 25$ \\
\hline 6 & $\nabla 1$ & Tokyo & 746 & $\nabla 3$ \\
\hline 7 & $\Delta 2$ & Sydney & 734 & $\Delta 10$ \\
\hline 8 & $\Delta 3$ & Beijing & 733 & $\boldsymbol{\Delta} 12$ \\
\hline 9 & $\Delta 7$ & Zurich & 732 & $\Delta 19$ \\
\hline 10 & $\Delta 10$ & Frankfurt & 730 & $\Delta 22$ \\
\hline 11 & $\nabla 4$ & Toronto & 728 & - \\
\hline 12 & $\Delta 6$ & Shenzhen & 726 & $\Delta 16$ \\
\hline 13 & $\nabla 3$ & Boston & 725 & $\Delta 3$ \\
\hline 14 & $\nabla 6$ & San Francisco & 724 & $\nabla 2$ \\
\hline 15 & $\Delta 4$ & Dubai & 722 & $\Delta 13$ \\
\hline 16 & $\Delta 1$ & Los -Angeles & 721 & $\Delta 9$ \\
\hline 17 & $\nabla 3$ & Chicago & 717 & $\nabla 1$ \\
\hline 18 & $\nabla 3$ & Vancouver & 709 & $\boldsymbol{\nabla} 8$ \\
\hline 19 & $\Delta 9$ & Guangzhou & 708 & $\boldsymbol{\Delta} 30$ \\
\hline 20 & $\nabla 8$ & Melbourne & 699 & $\boldsymbol{\nabla} 21$ \\
\hline
\end{tabular}

Source: The Global Financial Centres Index 24 September 2018. - [Electronic resource.] Access mode: https://www.longfinance.net/media/documents/GFCI_24_final_Report.pdf

As shown in Fig. 1 and table. 3 the US Federal reserve controls the lion's share of offshore financial flows. Luxembourg, Cayman Islands, Isle of Man, Jersey, Ireland, Mauritius, Bermuda, Monaco, Switzerland, the Bahamas are the best ten tax havens in the world, so «does anyone have any doubt that if, for example, the United States wanted, it would not have closed these offshore for a month? Theoretically, this can be done even sooner by simply 
turning off the companies of this country from the SWIFT system of world payments. ${ }^{19}$ Modern offshore companies have the best legal systems that reliably protect investments around the world. Any new necessary changes to the legislation are introduced quickly and effectively, which is not an achievable luxury for the political systems of countries such as the United States and the United Kingdom. Offshore companies accelerate global financial processes and contribute to the growth of the world economy. According to experts, the value of assets controlled through offshore companies exceeds USD 20 trillion. The United States and Europe are concerned that companies registered in offshore countries may be used to finance terrorism and for tax evasion by their citizens. There is a tough struggle of the security services of these countries against this, and not against offshore companies in general. But if offshore companies are used to be closer to the money of investors or the benefits of European civilization with more perfect legislation than in England, the European countries and the United States consider offshore as a tool for the existence of the world economy and their economies, notes Rodzynskyi Anatolii, Chairman of the NGO «Reforms against corruption» ${ }^{20}$.

Fig. 2 shows the evolution of global offshore wealth since 2001, estimated using the same methods and data sources as in Zucman (2013), but based on the latest available international investment positions of countries, we believe that the stock of offshore wealth remained within about $10 \%$ of world GDP, without much trend.

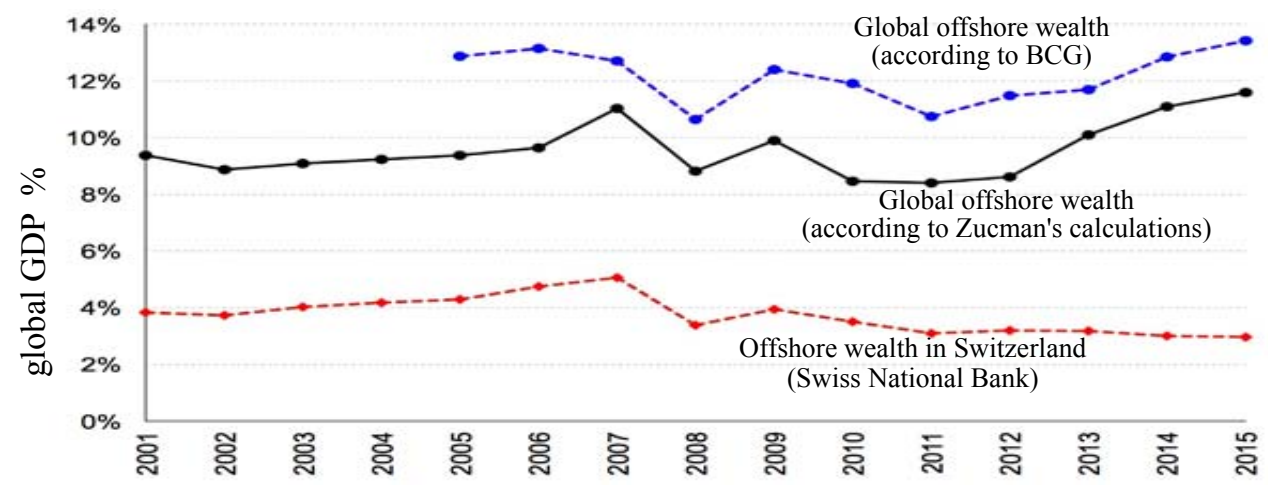

\footnotetext{
19 SWIFT (Society of Worldwide Interbank Financial Telecommunications) - is an international interbank information transfer and payment system. SWIFT International Payments is a convenient way to transfer money abroad from one's own account to an individual or legal entity. Requirements for sending SWIFT payment in foreign currency: name of the recipient bank; recipient's bank SWIFT code; recipient's account number (or international account number — IBAN); name (for an individual — surname, and first name) and address (residence) of the recipient; purpose of the payment (payment purpose, invoice number).

${ }^{20}$ Kakie offshoryi nuzhnyi Ukraine. [Electronic resource]. - Access mode: https://www.epravda. com.ua/rus/columns/2016/04/15/589562/: 10 Best Tax Havens in the world. [Electronic resource]. - Access mode: https://www.fool.com/investing/general/2016/01/03/10-best-tax-havens-in-the-world.aspx [In Russian].
} 
Notes: The lower axis reflects the global wealth held by households in all global tax havens at the end of each year as a share of world GDP. The bottom line shows the offshore wealth held by Swiss banks, estimated from the monthly banking statistics of the Swiss National Bank. The middle curve shows the estimate obtained through the application of the methodology of Zucman (Zucman) (2013) and update the results until 2015. The top line shows the Boston Consulting Group assessment, which is published annually in the BCG report.

Fig. 2. Global wealth in tax havens

Source: Alstadsжter Annette, Johannesen Niels, Zucman Gabriel. Who owns the wealth in tax havens? Macro evidence and implications for global inequality. Journal of Public Economics 162 (2018). - P. 93. [Electronic resource.] -Access mode: http://gabrielzucman.eu/files/AJZ2018.pdf

Where is the concentration of offshore wealth in the world, based on the number of cross-border Bank deposits managed in each offshore center, shown in Fig. 3. Switzerland lost its position as an offshore center through the crisis of 2008-2009, and Asian offshore centres were on the rise. The increase in offshore wealth was particularly noticeable in Hong Kong. Jersey, the Bahamas and the Cayman Islands in 2007, on the contrary, gained great popularity as offshore centres. From 2007 to 2015, the assets under management were increased by 6 times, and Hong Kong now ranks second after Switzerland.

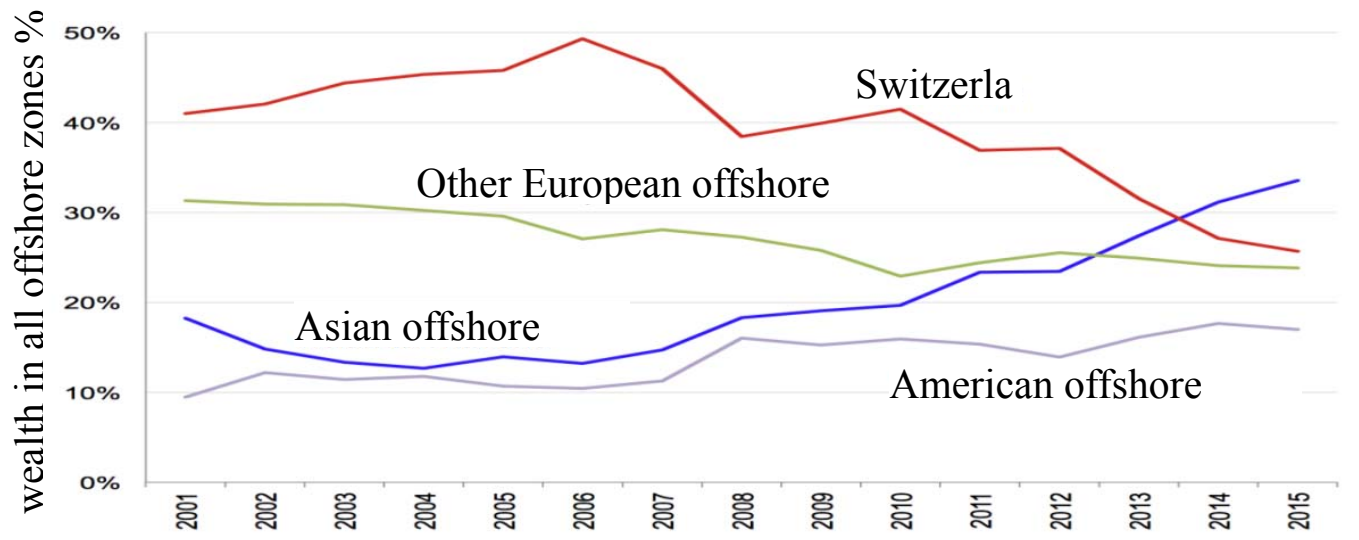

Notes: this indicator reflects the share of global offshore wealth managed in Switzerland, in other European offshore centres (Cyprus, Guernsey, Jersey, Isle of Man, Luxembourg, Austria, Belgium and the United Kingdom), in Asian offshore centres (defined as Hong Kong, Singapore, Macau, Malaysia, Bahrain, as well as the Bahamas, Bermuda and the Netherlands Antilles (see text), as in us offshore centres (defined as the Cayman Islands, Panama and the United States) (see text).

Fig. 3. Distribution of the world's offshore wealth

Source: Alstadsжter Annette, Johannesen Niels, Zucman Gabriel. Who owns the wealth in tax havens? Macro evidence and implications for global inequality. / Journal of Public 
Economics 162 (2018). - P. 93. [Electronic resource.] - Access mode: http://gabrielzucman.eu/files / AJZ2018.pdf

The distribution of offshore wealth in Switzerland is shown in Fig. 4. Countries above the 45-degree line have a greater share of Swiss wealth than their share of world GDP. This group is heterogeneous: it includes medium-sized oil exporters (Saudi Arabia, United through the Bank for international settlements $\left.-\mathrm{BIS}^{21}\right)$.

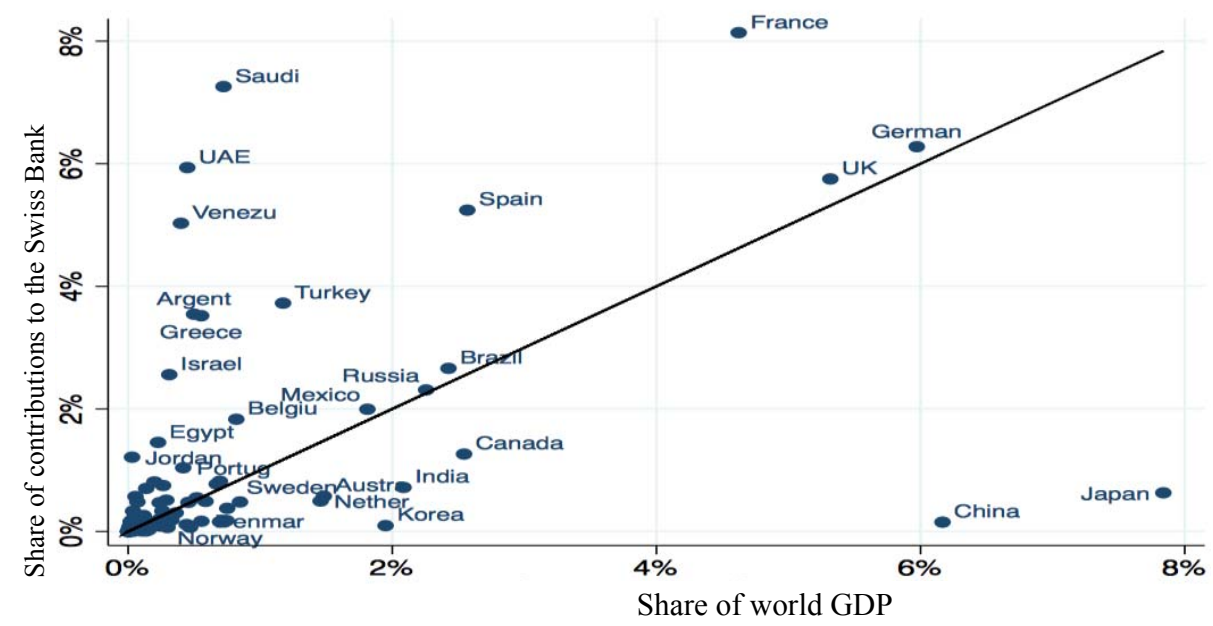

Notes: this distribution reflects, respectively, the share of each country in the total amount of offshore wealth managed by Swiss banks against its share of world GDP. Black line is the 45-degree line. Countries above the 45-degree line have more wealth in Switzerland than their share of world GDP, and vice versa, for countries below the 45-degree line. (All data as of 2007).

Fig. 4. Who owns wealth in Switzerland

Source: Alstadsжter Annette, Johannesen Niels, Zucman Gabriel. Who owns the wealth in tax havens? Macro evidence and implications for global inequality. Journal of Public Economics 162 (2018). - P. 93. [Electronic resource.] - Access mode: http: / gabrielzucman.eu/files/AJZ2018.pdf; Swiss national bank offers a negative interest. - 2017. P. 20. [Electronic resource.] -Access mode: https://www.snb.ch/en / mmr/reference/ banks_2017/source/banks_2017.en.pdf

Fig. 5 contrasts with the distribution of wealth in Switzerland and other offshore centres. Countries below the 45-degree line tend to favour Switzerland, while countries above the 45-degree line tend to favour other private wealth management centres, among which the largest in

${ }^{21}$ The Bank for International Settlements is the oldest international financial institution whose functions include the facilitation of cooperation between central banks and the facilitation of international financial settlements; it is also the center of economic and monetary research. 
2007 were Singapore, Luxembourg, Jersey and the Cayman Islands. Asian economies tend to have a small share of wealth in Switzerland, but a higher share that is managed elsewhere (particularly in Singapore, which serves predominantly Asian investors). Russia has wealth in Switzerland, and in other tax havens, mostly in Cyprus. A number of European countries, such as France, Belgium, Portugal, close to the 45degree line, because they have a significant share of wealth, which is managed from Luxembourg and Jersey. The Middle East countries, in most cases, prefer Switzerland, perhaps historically, because Switzerland was the only banking centre with a developed asset management industry during the oil boom of the 1970s.

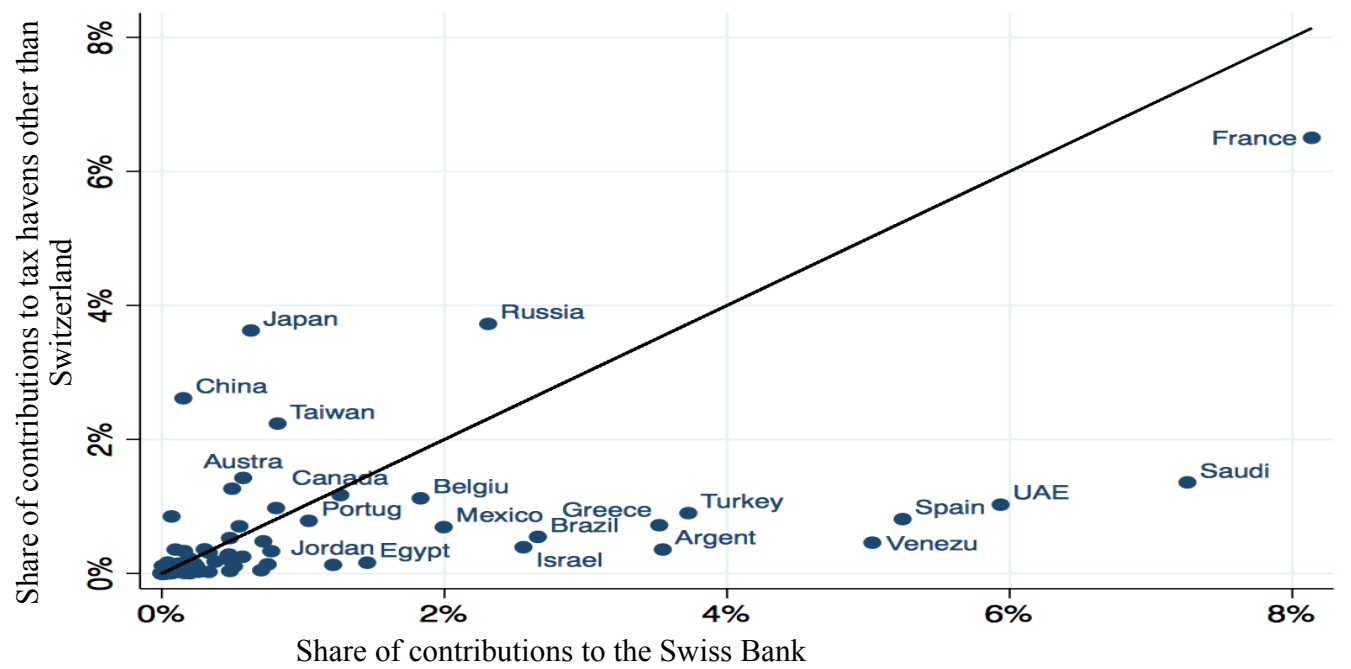

Notes: shares of countries in the total amount of offshore wealth held in tax havens other than Switzerland against its share in the total amount of offshore wealth held in Switzerland. Black line is the 45-degree line. Countries below the 45-degree line tend to prefer Switzerland over other offshore financial centres, and vice versa for countries above the 45-degree line. (All figures are for 2007). Tax havens other than Switzerland include: Cyprus, Guernsey, Jersey, Isle of Man, Luxembourg, Austria, Belgium, United Kingdom, Hong Kong, Singapore, Macau, Malaysia, Bahrain, Bahamas, Bermuda Netherlands Antilles, Cayman Islands, Panama and the United States. The United States is not shown in the graph through its emissions status; it has a much larger share of assets located outside of Switzerland (33\%) than in Switzerland (3\%).

Fig. 5. Who owns wealth in tax havens other than Switzerland

Source: Alstadsжter Annette, Johannesen Niels, Zucman Gabriel. Who owns the wealth in tax havens? Macro evidence and implications for global inequality. / Journal of Public Economics 162 (2018). - P. 94. [Electronic resource.] -Access mode: http://gabrielzucman.eu/files/AJZ2018.pdf; Swiss national bank offers a negative interest. - 2017 . - 
P. 20. [Electronic resource.] -Access mode: https://www.snb.ch/en/mmr/reference/ banks_2017/source/banks_2017.en.pdf

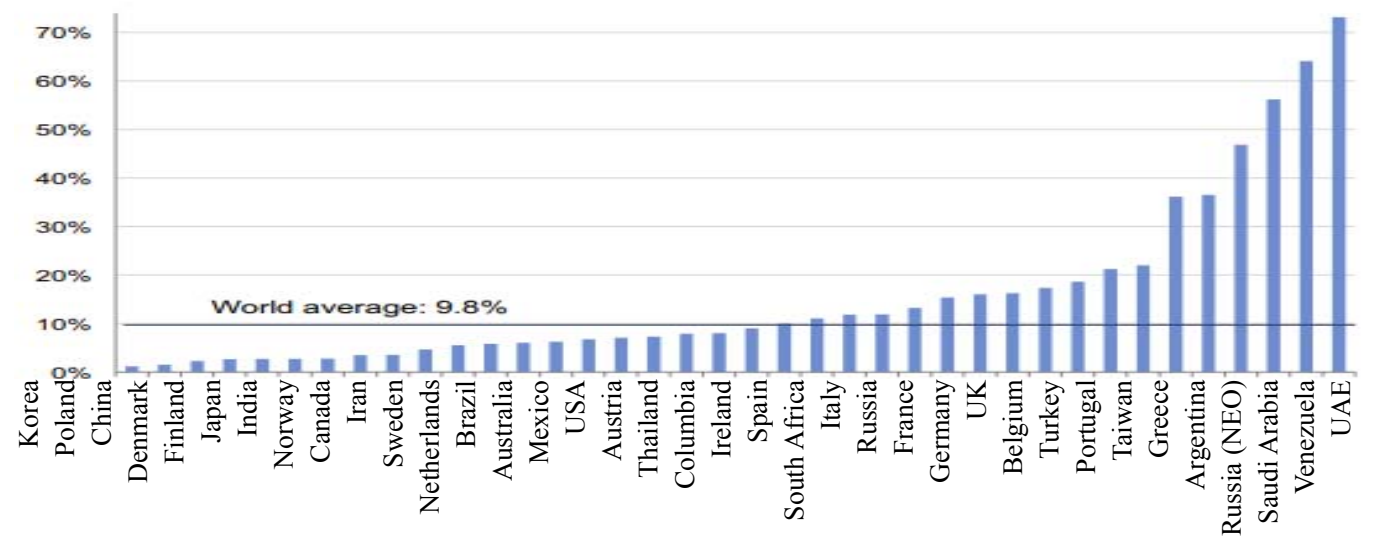

Notes: the number of households owned by offshore centres as a percentage of GDP (2007) The Sample includes all countries of the world out of more than USD 200 billion. of GDP in 2007.

Fig. 6. Offshore wealth in relation to GDP in \%

Source: Alstadsжter Annette, Johannesen Niels, Zucman Gabriel. Who owns the wealth in tax havens? Macro evidence and implications for global inequality. / Journal of Public Economics 162 (2018). - P. 95. [Electronic resource.] -Access mode: http:/gabrielzucman.eu/files/AJZ2018.pdf; Swiss national bank offers a negative interest. - 2017. - P. 20. [Electronic resource.] -Access mode: https://www.snb.ch/en/mmr/reference/ banks_2017/source/banks_2017.en.pdf

We get an estimate of the offshore wealth behind the country, adding to that wealth in Switzerland and other tax havens. The results shown in Fig. 6 shows the ratio of offshore wealth to GDP for all countries with more than USD 200 billion. of GDP, according to the methodology described in Novokmet et al (2017).

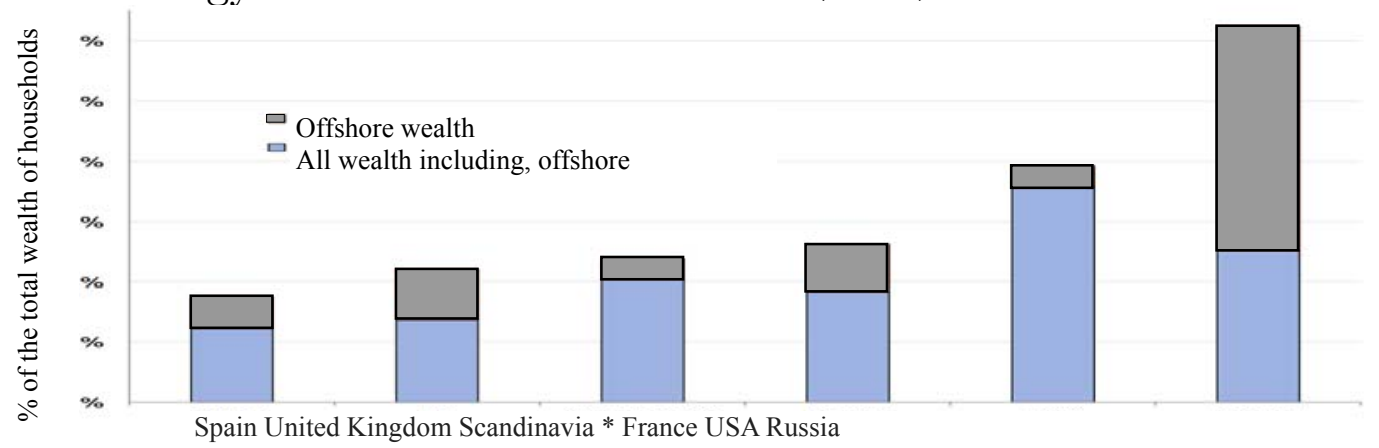

Notes: Top $0.01 \%$ of offshore wealth on average for the period of $2000-2009$ (the upper part of the figure).

*Scandinavia - the arithmetic mean of Norway, Sweden and Denmark.

Fig. 7. Offshore wealth and all wealth including, offshore 
Source: Alstadsжter Annette, Johannesen Niels, Zucman Gabriel. Who owns the wealth in tax havens? Macro evidence and implications for global inequality. Journal of Public Economics 162 (2018). - P. 98,99. [Electronic resource.] -Access mode: http://gabrielzucman.eu/files/AJZ2018.pdf; Swiss national bank offers a negative interest. - 2017. - P. 20. [English] [Electronic resource.] -Access mode: https:/ / www.snb.ch/en / mmr / reference/banks_2017/source/banks_2017.en.pdf

The top $0.01 \%$ of offshore wealth in the sample of countries compared to all wealth, including offshore, are shown in Fig. 7. Accounting for offshore assets significantly increases the share of wealth by $0.01 \%$, even in countries such as Scandinavian economies that do not extensively use tax havens. However, the magnitude of the effect differs between countries. In Scandinavia, the largest share of wealth is growing from $4 \%$ to about $5 \%$. Offshore wealth has a greater impact on inequality in the UK, Spain and France, where $30 \%-40 \%$ of the total wealth of the richest households is abroad. ${ }^{22}$

For comparison, fiduciary deposits from abroad by regions and countries for 2017 are presented in Fig. 8. Compared to 2016, the subsidiary funds managed by the banks increased by CHF 17.8 billion, or by $14.8 \%$ to CHF 138.2 billion. At that time, as domestic passive funds recorded a slight increase of CHF 0.9 billion to $\mathrm{CHF} 22.7$ billion, there was a significant increase of deposits from abroad - to CHF 16.9 billion, in the amount to CHF 115.6 billion. As for long-term deposits from abroad, the deposits of developed countries increased by $22.8 \%$, deposits from developing countries - by $35.2 \%$, and from offshore - by $7.8 \%$.

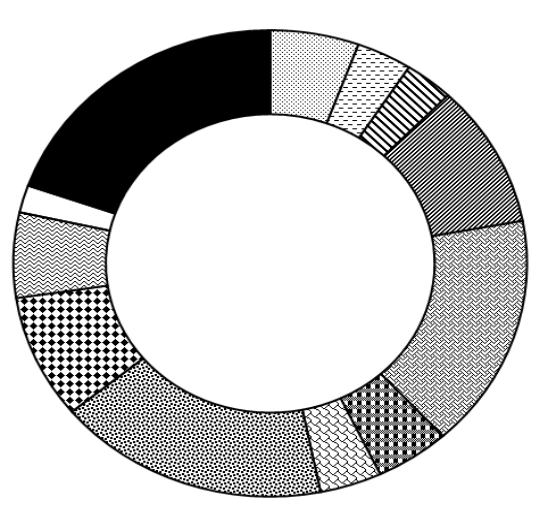

Developed countries $22.1 \%$

Great Britain $5.6 \%$

Cyprus $3.5 \%$

\$ Luxembourg $3.1 \%$

Other developed countries $9.9 \%$

Offshore centres $42.0 \%$

West Indies (UK) $16.2 \%$

Bahamas $4.7 \%$

Es Panama $3.9 \%$

Other offshore centres $17.2 \%$

Developing countries $36.0 \%$

Saudi Arabia $8.6 \%$

United Arab Emirates $5.9 \%$

ㅁ. Turkey $1.9 \%$

Other developing countries $19.6 \%$

Total: CHF 108.6 billion

${ }^{22}$ Alstadsceter Annette, Johannesen Niels, Zucman Gabriel. Who owns the wealth in tax havens? Macro evidence and implications for global inequality. // Journal of Public Economics 162 (2018). -P. 96 - 100. [Electronic resource]. — Access mode: http://gabriel-zucman.eu/files/AJZ2018.pdf 
Fig. 8 fiduciary deposits from abroad by region and country for 2017

Source: Swiss national bank offers a negative interest. - 2017. - P. 20. [Electronic resource.] -Access mode: https://www.snb.ch/en/mmr/reference/banks_2017/ source/banks_2017.en.pdf

Fiduciary funds are accepted in the currency in which they are invested (banks do not carry out any currency transfers). Currency distribution also depends on the movement of interest rates in the money market, given that this is where full deposits are placed. Against the background of higher interest rates in us dollars in the money market, deposits were invested in USD, respectively; this item increased by CHF 17.1 billion, to a total of CHF 108.1 billion.

Relatively low rates of capital growth were invested in euros ( $\mathrm{CHF}$ 0.5 billion, and consequently up to CHF 9.2 billion), and investments in 0.1 billion Swiss francs and rose to $\mathrm{CHF} 3.8$ billion. The value of long-term business in USD has been rising steadily in recent years, with inventories in USD amounting to $78.2 \%$ at the end of 2017. The shares of mutual funds invested in EUR and CHF were relatively small -6.6 per cent and 2.7 per cent respectively.

Ukraine in the offshore world

Ukraine does not stand aside from the process of business offshoring. In Ukraine, «small and medium-sized businesses do not need offshore - the tax rate on the simplified tax system - from $1 \%$ to $5 \%$, which makes our country a real offshore from the point of view of Europeans and Americans. Another thing is that corruption makes Ukraine unattractive for investment. To eliminate this, reforms are urgently needed. So, perhaps, it is necessary to accept that offshore is a tool for large businesses around the world to invest and attract investment. Offshore companies can become a medicine for the Ukrainian economy, one of the channels of investment in the country, and therefore - the growth of its economy and income of Ukrainians, «says Rodzynskyi Anatolii, Chairman of the NGO «Reforms against corruption.» ${ }^{23}$

In fact, offshores can become a kind of medicine for the Ukrainian economy at the expense of minor taxes (the country will turn into onshore like Cyprus or Malta) and the concentration of significant capital of the world can stimulate financial responsibility and discipline to global partners (global companies and states), as well as slow down the development of corruption in the country. A lot or a little of Ukrainians and domestic business uses offshore? The answer is

\footnotetext{
23 Kakie offshoryi nuzhnyi Ukraine. [Electronic resource]._- Access mode: https://www.epravda.com.ua/rus/columns/2016/04/15/589562/
} 
unexpected - no more than business and citizens of most other countries. Data published by the International Consortium of Investigative Journalists (ICIJ) show that Ukraine occupies a negligible place in the global offshore web. Only $0.23 \%$ of nodes or 1,689 of 719,000 are directly related to Ukraine (for comparison, the share of Ukraine's GDP in world GDP is about $0.12 \%$ ), which are associated with $0.25 \%$ of links (3,095 of 1.3 million). For comparison, the number of nodes that are associated with Russia $3.3 \%$, the UK $4.3 \%$, Switzerland $6.6 \%$, China 9.2\%, Hong Kong $14.3 \%$ (Fig. 9). Even if we compare the number of offshores with the scale of economies, it turns out that Ukraine is not the leader of offshores using the services of Mossack Fonseca and Commonwealth Trust Limited. For example, the number of offshore companies associated with Russia is almost 15 times higher than the number that concerns Ukraine, while its economy is 14 times larger than ours.

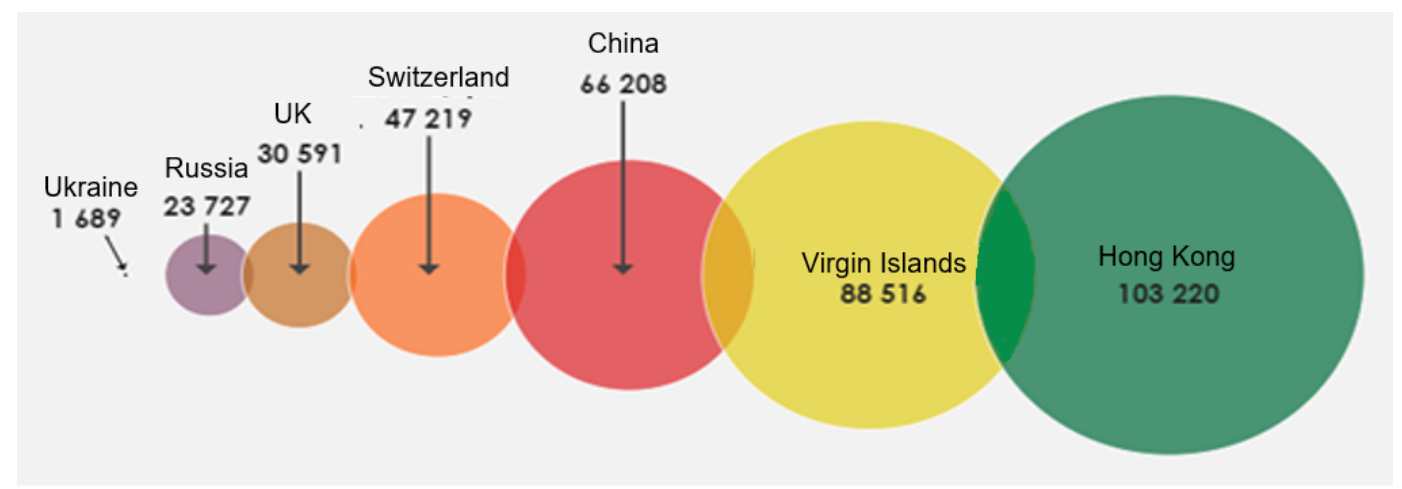

Note: the size of the circle is the number of objects in the global offshore network

Fig. 9. The place of Ukraine in the global offshore network

Source: Anthology of offshore: guide to Ukrainian offshore web. [Electronic resource.] Access mode: https://voxukraine.org/longreads/panama/index_ua.html.

Ukraine is a dwarf in an offshore galaxy. But even such small objects can have a complex structure (Fig. 10). At first glance, it may seem that the Ukrainian offshore network is a tangle that can not be untangled and which consists of many representatives, offshore companies, intermediaries and contact addresses. But that's not the case. If you look closely, the network consists of several large and many 
small clusters (Fig. 10). The size of a node depends on the number of links to other nodes.

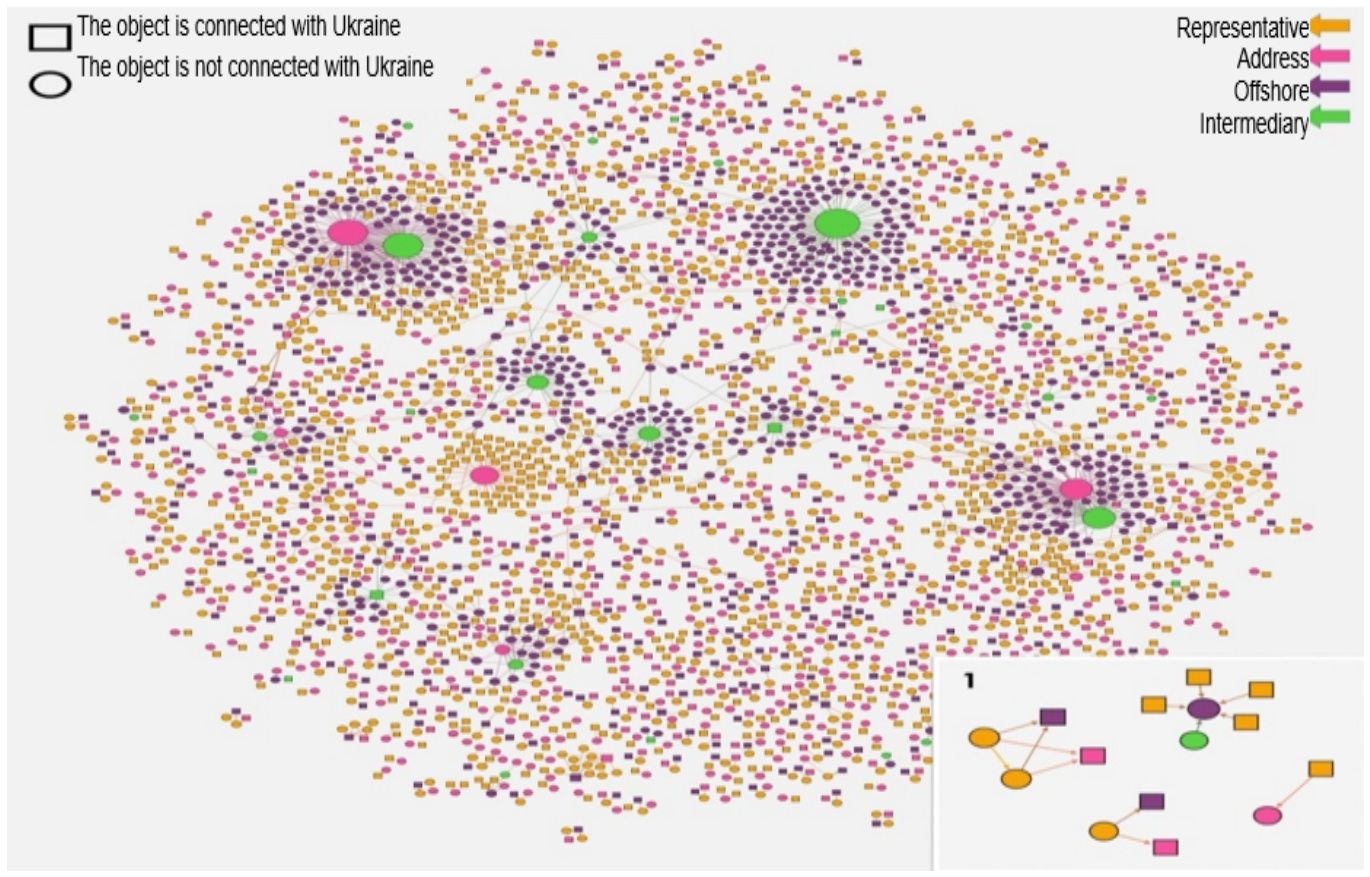

Fig. 10 «rey» galaxy: Ukrainian offshore network

Source: Anthology of offshore: guide to Ukrainian offshore web. [Electronic resource.] Access mode: https://voxukraine.org/longreads/panama/index_ua.html.

The largest number of links to other nodes is inherent to intermediaries. It is obvious that the role of an intermediary in the offshore business is very high. The main reasons why the representative requests the intermediary for assistance - confidentiality and offshore registration simplification. Experienced intermediaries are familiar with effective agents (for example, Mossack Fonseca) who work in many jurisdictions with low taxes; have experience in processing a large number of necessary documents; are ready to provide the representative with the desired level of anonymity.

20 intermediaries who are registered in Ukraine are specified in Panama documents. 9 of them are individuals, the other 11 are legal entities $^{24}$.

\footnotetext{
${ }^{24}$ Antolohiia ofshoriv: putivnyk ukrainskvi ofshornii pavutyni. [Electronic resource]. - Access mode: https://voxukraine.org/longreads/panama/index_ua.html. [In Ukrainian].
} 
Rating of intermediaries in accordance with the number of registered offshore companies is as follows:

1. ANGLO BUSINESS ADVISORS LTD. - 110;

2. Tax Consulting U. K. Ltd. - 93;

3. C\&A Limited - 71;

4. C \& A PARTNERS LLP - 38;

5. K. A. C. LIMITED -38 .

Ukraine is a member of the international offshore system of the world, but its share is very small.

How complicated the offshore schemes are

The clusters that make up the Ukrainian offshore network can be interpreted as offshore schemes with varying degrees of complexity. The simplest scheme consists of three nodes and two links - «Basic level» (Fig. 11). The simplicity of the scheme does not prevent its popularity: $40 \%$ of all businesses use/used this scheme.

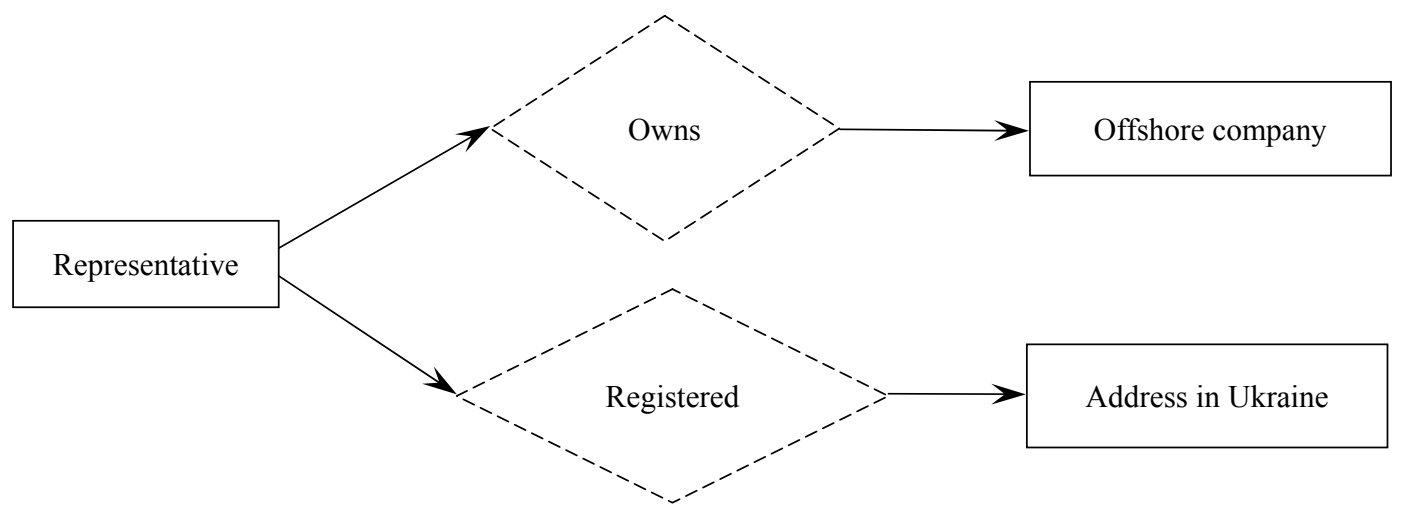

Fig. 11 offshore scheme «Basic level»

Source: Anthology of offshore: guide to Ukrainian offshore web. [Electronic resource.] Access mode: https://voxukraine.org/longreads/panama/index_ua.html.

The structure of the cluster can be complicated when there are intermediaries, representatives register multiple addresses, in place of one offshore appears two or more. So it happened with the oldest offshore company, which has Ukrainian roots, Rado Ltd. Now it is part of the largest and most complex» offshore cluster, which consists of 275,275 nodes (123 offshore, 12 addresses, 3 intermediaries and 137 representatives) and 454 links between them (Fig. 12). The cluster consists of three parts connected by two representatives: Multihold Limited (Panama) and BPT Legal Adviser (not defined). A distinctive feature of the cluster is the key position of intermediaries and addresses 
through which all 123 offshore companies were opened. If you remove the intermediaries, the cluster will break up into a large number of small structures.

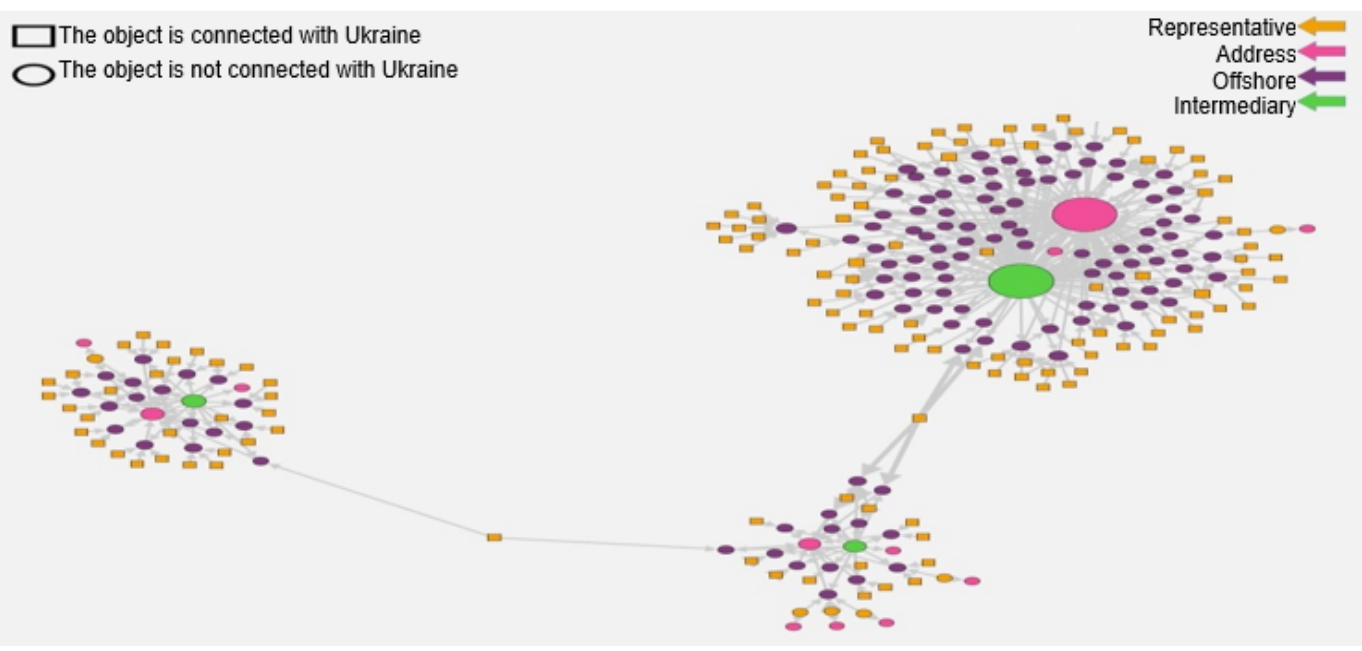

Fig. 12 The largest offshore cluster

Source: Anthology of offshore: guide to Ukrainian offshore web. [Electronic resource.] Access mode: https://voxukraine.org/longreads/panama/index_ua.html.

If we decompose the cluster into separate components, we will see that they are typical. We can say that the largest cluster consists of a set of identical offshore schemes, which we call «the Basic level with an intermediary» (Fig. 13).

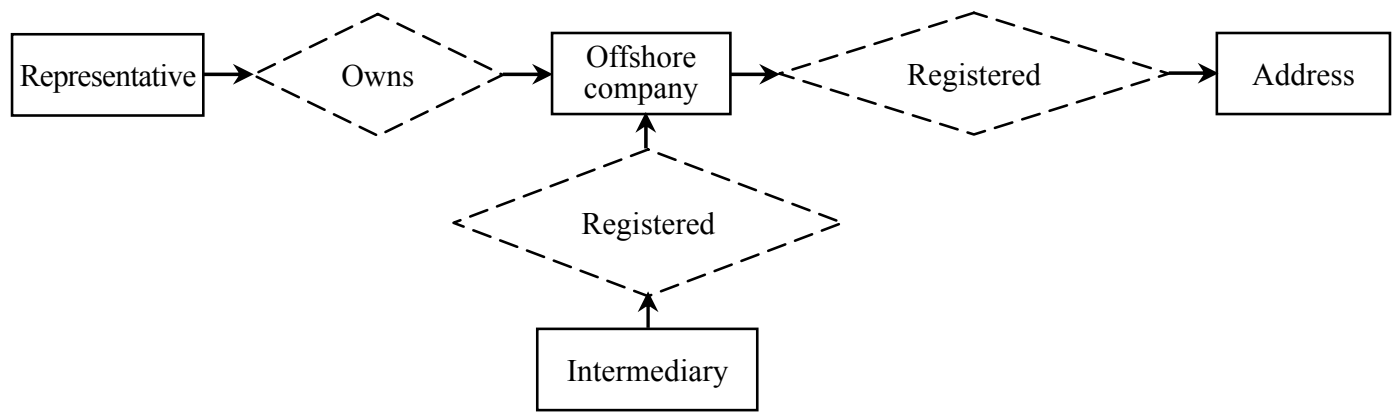

Fig. 13 offshore scheme «Basic level with intermediary»

Source: Anthology of offshore: guide to Ukrainian offshore web. [Electronic resource.] Access mode: https://voxukraine.org/longreads/panama/index_ua.html. 
This typical scheme consists of 4 nodes and 3 links:

1. The representative owns an offshore (officer $\rightarrow$ entity);

2. The intermediary registered an offshore (intermediate $\rightarrow$ entity);

3 . Offshore is registered at a specific address (entity $\rightarrow$ address) ${ }^{25}$.

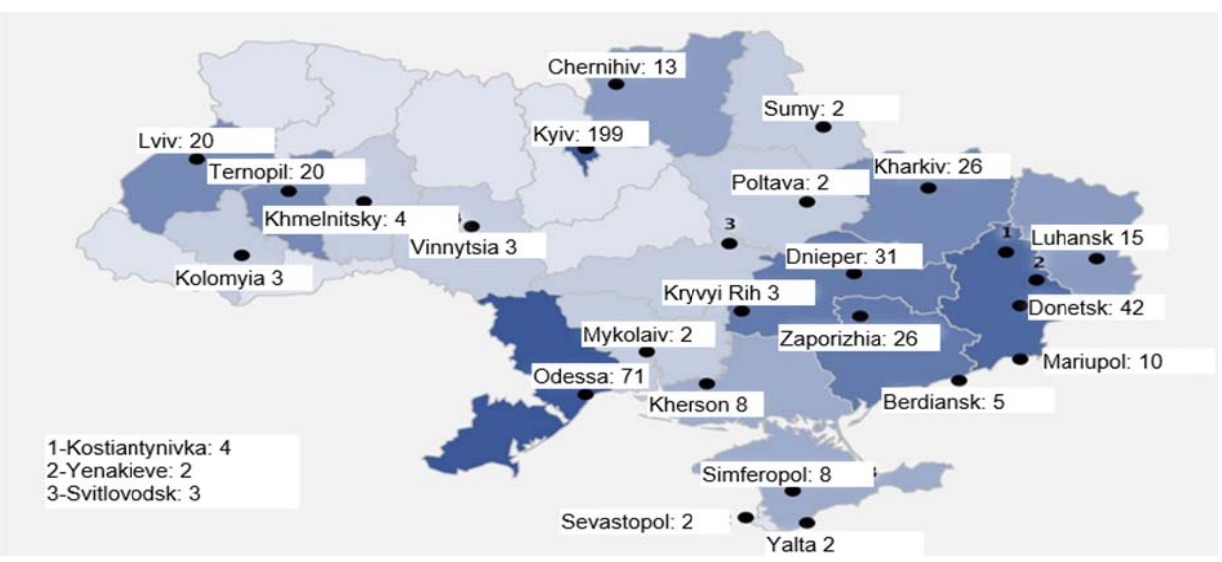

Fig. 14 Geographical distribution of representatives of offshore companies

Source: Anthology of offshore: guide to Ukrainian offshore web. [Electronic resource.] Access mode: https://voxukraine.org/longreads/panama/index_ua.html.

The activity of «Ukrainian schemes» of capital withdrawal to offshore zones is analysed and the following three schemes that are the most common in the international offshore practice of the world are considered. The simplest scheme is the «export/import» scheme of «mediation» and «construction» (Fig. 15, 16 and 17 respectively).

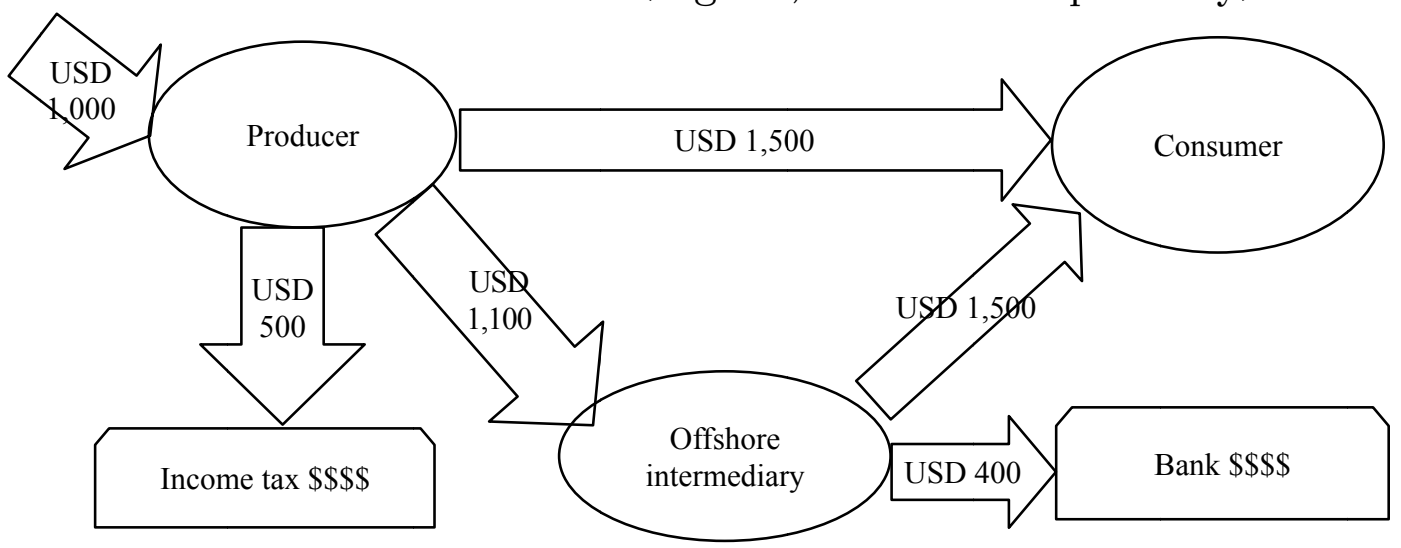

\footnotetext{
${ }^{25}$ Skladnist ofshornykh zon v Ukraini. [Electronic resource]. — Access mode:
} https://forum.pravda.com.ua/index.php?topic=923744.0 [In Ukrainian]. 
Fig. 15 Export/import offshore scheme

«Export/import scheme» is incredibly simple and available to everyone. In this scheme, the offshore company buys/sells the goods at the lowest price, which can only be specified in the contract, and then resells the goods/services to the final buyer at the market price, keeping a tax-free and not controlled by the local authorities difference. This is done in such a way, two contracts are signed, the first between the offshore and the exporter/importer, in which the consignee is the end buyer of the goods/services and the second - between the offshore, which acts as the seller and the buyer (the consignee for the first contract). The scheme has been used in international business practice for a long time.

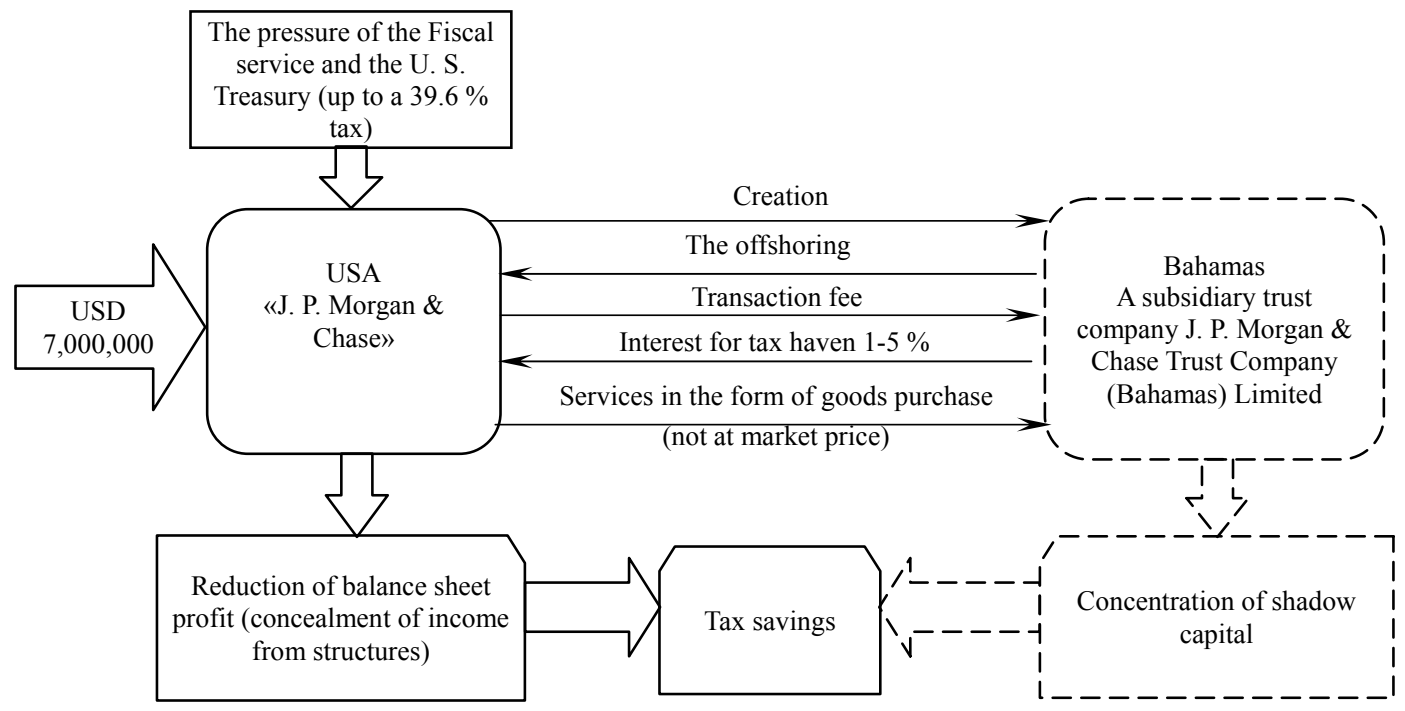

Fig. 16 Intermediary scheme

«Intermediary scheme», it is also called «Agency» is created by an offshore company network of agents in those countries in which it plans to operate (trade, provide services, etc.). These agents, acting on the terms of the «Agency agreement», conclude the necessary contracts with contractors, according to which all payments go to the accounts of an offshore company. Accordingly, no taxes are paid from them, and the agents themselves receive from the company some minimum Agency fee, for example, $1 \%$ of revenue or even less, from which they pay taxes in their countries of residence. 
The following scheme is used in construction. In this case, the company registered in the offshore acts as the General contractor, it is transferred all the payment for the construction works. At the same time, a resident construction company is being created, which acts as a subcontractor: an offshore company transfers to it the net cost of construction materials and work performed. As a result, the subcontractor does not earn anything, or his profit is scanty, respectively, negligible and taxes, and all real profits remain in the offshore company.

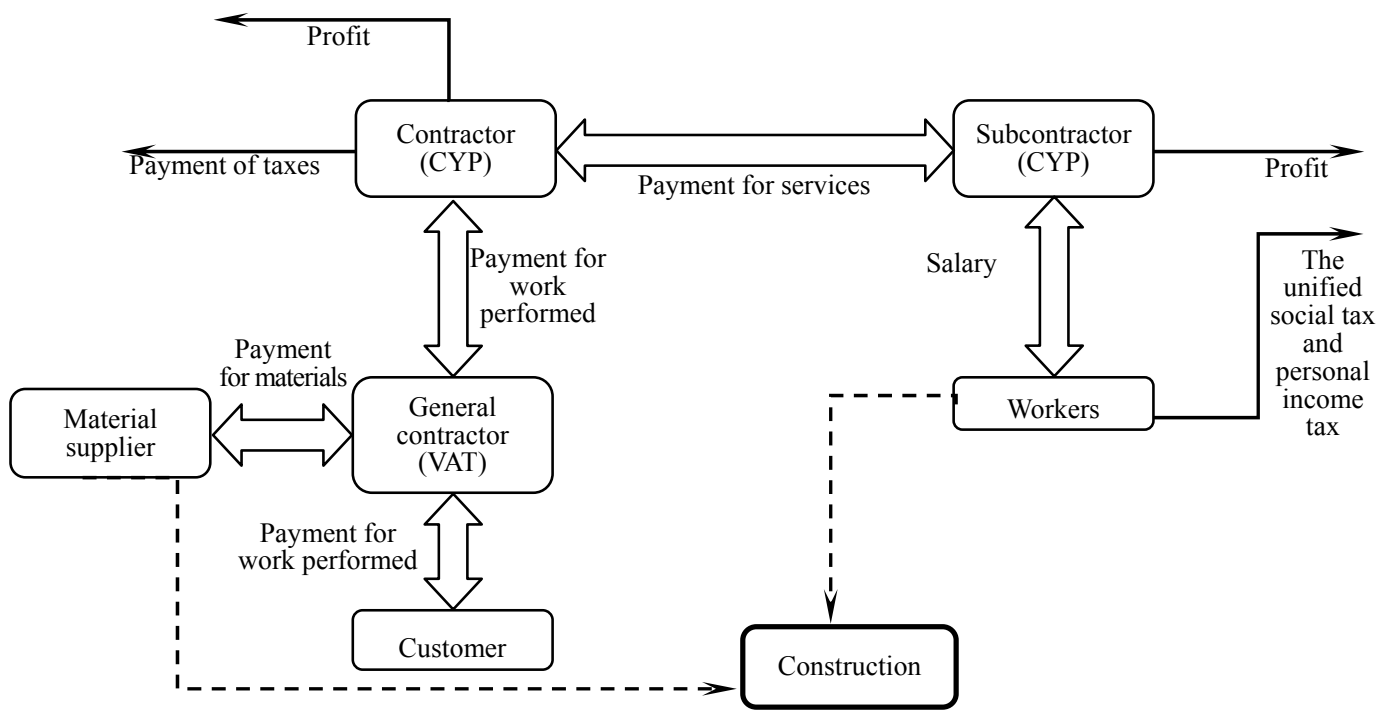

Fig. 17 Offshore scheme in construction

\section{De-offshorization and the fiscal security of Ukraine}

The need to ensure financial (including fiscal) security is becoming an even more pressing issue through the problem of too rapid globalization of the world economy, which entails the possibility of an imbalance of competition and monopolization of the market by individual States, which will disrupt the environment of competitive coexistence of countries. In the context of the difficult economic situation in Ukraine, which is caused by a shortage of own resources and a reduction in business activity, there is a need to take measures aimed at ensuring an appropriate level of financial security and, especially, its tax component. In the process of Ukraine's participation in the world integration processes, the issues of financial security are of particular relevance. Financial security, on the one hand, is a system of 
indicators that ensure the effective functioning of the financial system and its security through the prism of compliance with the balance between the recommended and actual values of indicators; and on the other hand, from the static side, it is a state of financial, monetary, currency, banking, budget, tax, investment, customs and tariff and stock systems, which are characterized by balance, resistance to internal and external negative impacts, the ability to prevent external financial expansion, ensure the effective functioning of the national economic system and economic growth. At the present stage, there is a weakening of the financial security of the state, which is caused primarily by internal systemic changes in each structural element of financial security (See. Fig. 18).

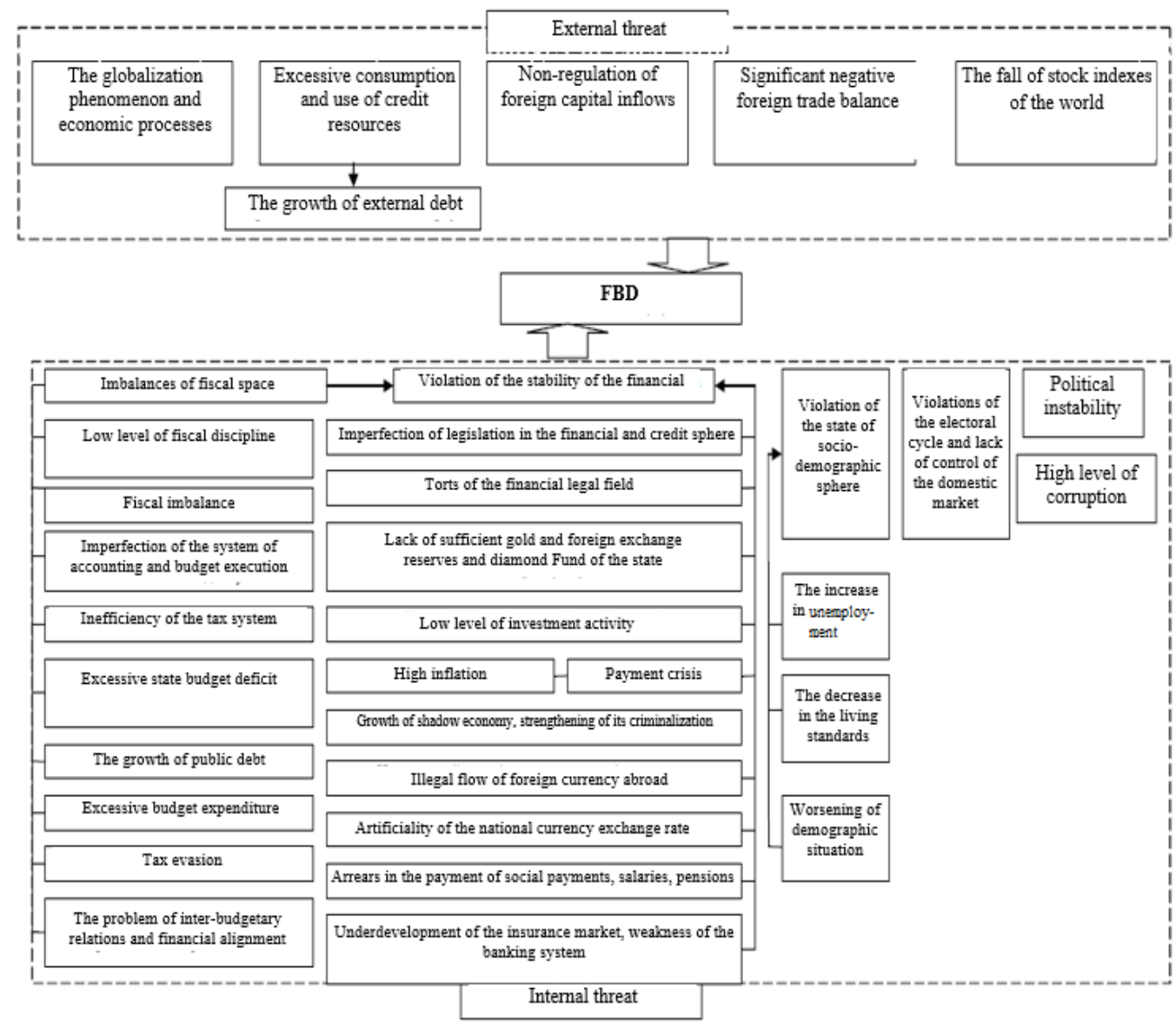

Fig. 18 Threats to fiscal security 
Source: developed by the authors (and a Course of lectures on the discipline rInternational Economic Security» (Z.O. Lutsyshyn, 2011-2017).

In order to ensure the financial security of the state, an important point is the implementation of constant monitoring of its main indicators. Ensuring such a monitoring process can be achieved through methodological support for the measurement of financial security indicators, their comparison with the limit values and the use of quantitative parameters for the preparation of analytical materials and scientific justification of management decisions. According to the «Guidelines for assessing the level of economic security of Ukraine» ${ }^{26}$, which was developed by the National Institute of International Security Problems, the method of calculation of financial security indicators is proposed:

1) the level of inflation is manifested in the growth of prices, which leads to the depreciation of funds and reduces the purchasing power of the population and businesses. The level of inflation in Ukraine is determined by the Statistical Committee of Ukraine and is calculated as a percentage, depending on the change in the value of the consumer basket of basic goods (consumer price index);

2) the timeliness and ability of the state to repay debts is determined through the threshold value of the debt - to-GDP ratio. In international practice, debt is defined as «safe», as the fact that it does not exceed $60 \%$ of $\mathrm{GDP}^{27}$. In Ukraine, unfortunately, this recommendation is not implemented;

3 ) the state budget deficit is the excess of budget expenditures over its revenues. The level of the budget deficit is determined by the ratio of the deficit (BD) to the annual GDP (GDP);

4) the level of monetization of the economy - this indicator actually reflects the level of provision of the economy with monetary resources. This indicator is defined as a percentage of the ratio of the money supply per M3 unit (MS M3) to the annual GDP;

5) the cost of Bank loans is determined by the annual interest that the borrower pays to the commercial Bank for the use of loans. The attractiveness of lending depends on the level of interest rate, which is directly formed from the discount rate of the Central Bank;

6) international reserves of Central banks - the level of such reserves depends on the external stability of the national currency, which is determined by the stability of its exchange rate relative to

\footnotetext{
${ }^{26}$ Nakaz Ministerstva ekonomiky Ukrainy vid 29 zhovtnia 2013 r. No. 1277 «Pro zatverdzhennia Metodyky rozrakhunku rivnia ekonomichnoi bezpeky Ukrainy» [Electronic resource]. — Access mode: http://search.ligazakon.ua/1_doc2.nsf/link1/ME07222.html.

27 Neshko R. The concept of national financial security and methods of its evaluation / R. Neshko, V. Matviychuk // Economic and Law Paradigm of Modern Society. — 2016. — P. 84-93.
} 
other currencies, as well as the external solvency of the state in relation to the repayment and servicing of external debts.

Table 3

THE CALCULATION OF THE TAX SECURITY INDICATORS OF UKRAINE

\begin{tabular}{|l|l|l|l|l|l|l|l|l|l|}
\hline \multicolumn{1}{|c|}{ Indicators } & $\begin{array}{c}\text { Thresh } \\
\text { old } \\
\text { value }\end{array}$ & 2010 & 2011 & 2012 & 2013 & 2014 & 2015 & 2016 & $2017^{*}$ \\
\hline $\begin{array}{l}\text { Level of tax integrity } \\
\text { (\%) }\end{array}$ & $\geq 95$ & 90 & 97 & 96 & 94 & 94 & 93 & 94 & 95 \\
\hline $\begin{array}{l}\text { Level of total tax } \\
\text { burden (\%) }\end{array}$ & $\geq 30$ & 33.78 & 35.98 & 36.80 & 35.80 & 34.05 & 34.22 & 35.28 & 37.8 \\
\hline $\begin{array}{l}\text { Level of tax debt of } \\
\text { taxpayers (\%) }\end{array}$ & $\geq 5$ & 6.84 & 2.61 & 2.67 & 3.11 & 7.00 & 6.67 & 5.33 & 9.2 \\
\hline $\begin{array}{l}\text { The coefficient of } \\
\text { efficiency of } \\
\text { administration of tax } \\
\text { revenues }\end{array}$ & $\geq 1$ & 0.94 & 1.02 & 0.88 & 0.93 & 0.94 & 0.99 & 1.00 & 1.00 \\
\hline Elasticity coefficient & $\geq 1$ & 1.97 & 1.74 & 0.95 & -0.42 & 1.32 & 1.45 & 3.79 & 3.9 \\
\hline $\begin{array}{l}\text { The coefficient of } \\
\text { performance of the } \\
\text { fiscal authorities }\end{array}$ & $\geq 5$ & 4.99 & 2.05 & 2.81 & 3.66 & 4.04 & 6.84 & 6.60 & 6.85 \\
\hline $\begin{array}{l}\text { The level of } \\
\text { shadowing of the } \\
\text { economy (\% of } \\
\text { GDP) }\end{array}$ & $\geq 30$ & 38 & 34 & 34 & 35 & 41 & 45 & 37 & 39 \\
\hline
\end{tabular}

Source: Podik I. I. Assessment of the current state of tax security of Ukraine / Economy and the state. - No. 4/2017. - P. 46. [Electronic resource.] Access mode: http: / / www. economy.in.ua/pdf /4_2017/11. pdf; *calculated by the authors

So, financial security is a state of the financial, monetary, budgetary, monetary, banking and tax system, which can ensure the effective functioning of the state, maintaining its economic stability in the global environment. Considering in detail the structure of financial security of the state, it is possible to determine one of its important elements tax security, which through its fiscal function is aimed at filling the budget and ensuring the ability of the state to perform its duties in full.

According to $\mathrm{V}$. Ishchenko «tax security is a part of the financial security of the state, which is determined by the presence of the formed tax system, the optimal level of taxation, which provides sufficient content, through tax revenues of the budget for the state to perform its functions, and also ensures the development of the real 
sector of the economy and social protection of the population. ${ }^{28}$ In the opinion of L. L. Petrenko «tax security is the state of the tax system, which is characterized by the steadiness and stability of all its elements, which implies the ability to protect the economic interests of the state and to resist external and internal threats, the possibility of implementing and developing the tax potential of the country, the effective use of the competitive advantages of the tax system in the context of globalization. ${ }^{29}$ D. Tykhonov defines tax security as «the state of the economy and institutions of power, which ensures guaranteed receipt of tax payments to the budget, protects national interests, social orientation of tax policy, sufficient defence potential even under adverse conditions of development of internal and external processes.» ${ }^{30}$

Tax policy at the same time defines and is a part of the tax security - a set of measures aimed at the implementation of the plan to fill the budget. Tax security occupies one of the key places in the system of components of the financial security of the state through its chain nature of impact, that is, in the case of instability of tax security, the balance of budget, debt, monetary and other types of security is lost. The imperfection of tax security is determined by the inefficiency of the tax policy, which makes it almost impossible to implement the strategic priorities of financial security (See. Fig. 19).

Tax policy is the main tool for creating a stable tax system in Ukraine, the task of which is to ensure a sufficient amount of payments to the budgets of all levels, the effective functioning of the state economy, a fair approach to taxation of all categories of taxpayers, as well as the creation of conditions for the subsequent integration of Ukraine into the world financial space. The main factors that form a threat to financial security from the imperfect tax security and its component - the tax policy is:

- high level of shadow economy;

- lack of an effective mechanism to reduce tax debt;

- unweighted mechanism for granting tax benefits;

- inefficiency of methods of combating illicit trafficking in excisable goods and understatement of the tax base;

\footnotetext{
${ }^{28}$ Ishchenko V. V. Podatkova skladova finansovoi bezpeky derzhavy / V. V. Ishchenko // Visnyk ekonomiky transportu i promyslovosti. - 2012. - No. 37. - p. 36

Petrenko L. M. Podatkova bezpeka yak skladova finansovoi bezpeky derzhavy / L.M. Petrenko // Modeliuvannia ta informatsiini systemy v ekonomitsi: zb. Nauk. Prats; M-vo osvity i nauky Ukrainy, DVNZ «Kyiv. Nats. Ekon. Un-t im. V. Hetmana»; vidp. Red. V.K. Halitsyn. - 2012. - Vyp. 86. - p. 89

Cited: Lutsenko I. S. Metodychnyi pidkhid do otsiniuvannia rivnia podatkovoi bezpeky derzhavy / I. S. Lutsenko // Naukovyi visnyk Khersonskoho derzhavnoho universytetu. - 2015. - No. 12. - C. 160; Skladnist ofshornykh zon v Ukraini. [Electronic resource]. — Access mode: https://forum.pravda.com.ua/ index.php?topic $=923744.0$
} 


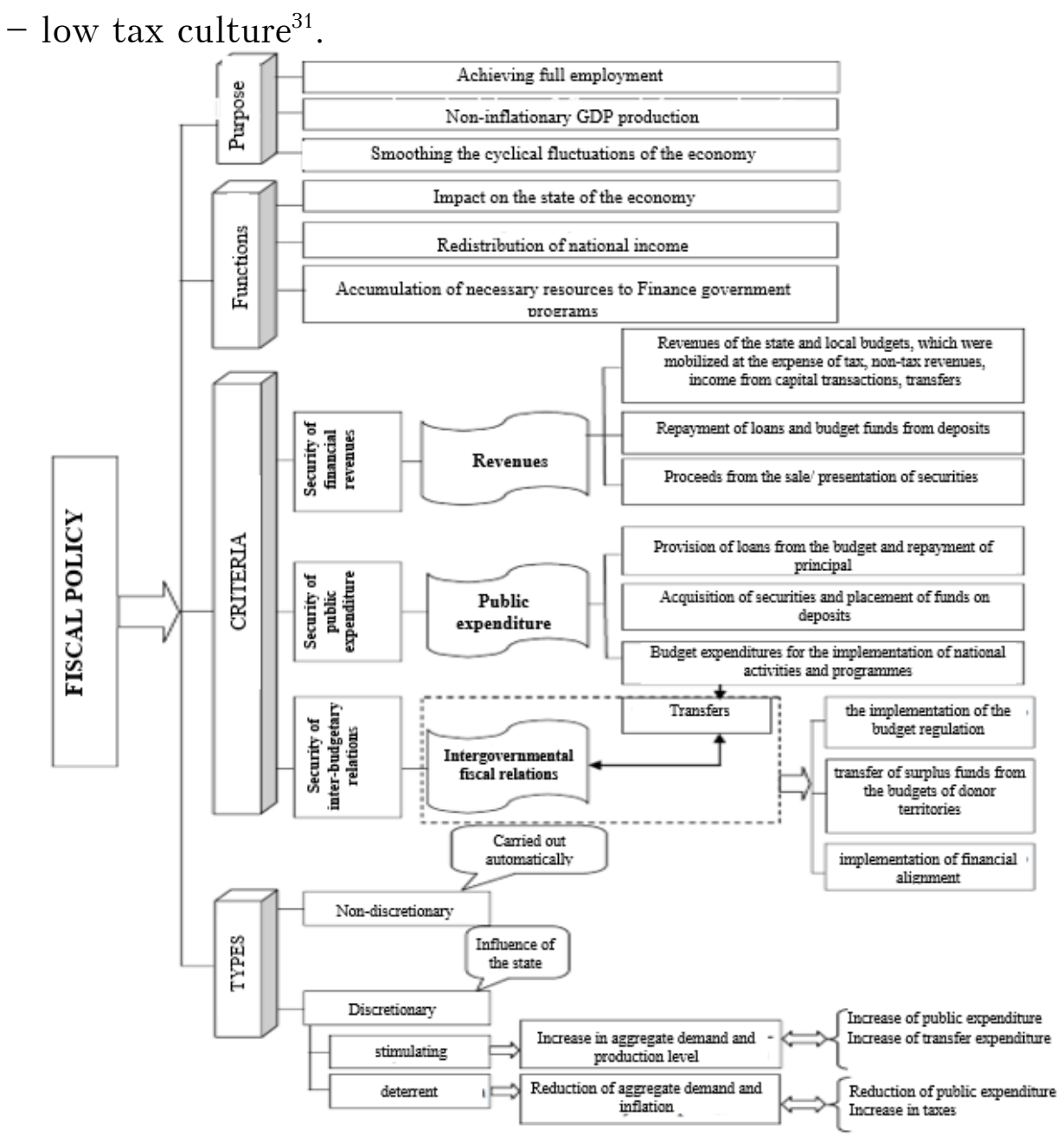

Fig. 19 Structural components of fiscal policy

Source: developed by the authors (and a Course of lectures on the discipline»International Economic Security» (Z.O. Lutsyshyn, 2011-2017).

$\mathrm{n}$ an article published in the journal Nature, the authors ( $\mathrm{J}$. GarciaBernardo, J. Fichtner, F. W. Takes and E. M. Heemskerk) studies conclude that a total of $47 \%$ of corporate offshore investments are made through the Netherlands (23\%), the UK (14\%), Switzerland (6\%),

${ }^{31}$ Neshko R., Matviichuk $V$. Podatkova bezpeka derzhavy yak zaporuka stabilnoi finansovoi bezpeky Ukrainy// Visnyk studentskoho naukovoho tovarystva DonNU imeni Vasylia Stusa// Neshko R. M., Matviichuk V. I. -Tom 2.No.8.-2016. [Electronic resource]. — Access mode: http://jvestnik-sss.donnu.edu.ua/article/view/3914 
Singapore $(2 \%)$ and Ireland $(1 \%)^{32}$. At the same time, 18 of the 24 most popular tax havens in the past were colonies or dependent territories of the UK, and some retain this status until now, the study notes. In the top ten offshore only Luxembourg and Taiwan do not have such close ties with the UK; the British Virgin Islands are at the top of this list. According to various sources, the countries of the European Union annually miss from 43 billion euros to 175 billion euros in tax revenues due to the use of offshore. In the USA, multinational corporations hide from taxes in offshore at least USD 130 billion a year. According to estimates of the International monetary Fund and the tax Justice Network, if the profits of companies are taxed at the place of economic activity, multinational corporations would pay USD 500-650 billion more taxes worldwide. Of this amount, they lose about USD 200 billion taxes a year, which is 1.5 times more than international assistance for the development of these states (USD142.6 billion in 2016) $)^{33}$.

To increase the level of financial security of Ukraine and its component - tax policy, it is important to introduce a number of measures:

- determination at the legislative level of criteria requirements for the permissible state of tax security ${ }^{34}$;

- stabilization of tax legislation in terms of changes in tax rates, reduction of the tax rate on wages, unified social tax, reduction of terms and tax base and providing more severe penalties for violation of tax legislation;

- active implementation of policies to improve the level of tax culture, informing the public about the peculiarities of the recovery of a tax on electronic resources, television, newspapers, etc;

- creation in the regions of state consulting centres of fiscal authorities, which will be able to provide not only free, but also paid assistance (which will be cheaper than private) in the field of taxes;

- reduction of tax debt by recovery from private debtors - 35 through the mechanism of gradual write-off of a certain amount of funds

\footnotetext{
32 Javier Garcia-Bernardo, Jan Fichtner, Frank W. Takes \& Eelke M. Heemskerk. Uncovering Offshore Financial Centers: Conduits and Sinks in the Global Corporate Ownership Network. [Electronic resource]. Access mode: https://www.nature.com/articles/s41598-017-06322-9

3 Nazvanyi stranyi, cherez kotoryie transnatsionalnyie korporatsii chasche vsego vyivodyat dengi $\mathrm{v}$ offshor. [Electronic resource]. - Access mode: https://news.finance.ua/ru/news/-/407220/nazvany-strany-cherez-kotoryetransnatsionalnye-korporatsii-chashhe-vsego-vyvodyat-dengi-v-offshor

${ }^{4}$ It is suggested to take as a basis the «Methodology for calculating the level of economic security of Ukraine» of October 29, 2013 No. 1277 of the Ministry of Economic Development and Trade, and it is proposed to reduce the marginal level of shadowing of the economy to $20 \%$, and the level of tax debt to $5 \%$.

See: Neshko R., Matviichuk V. Podatkova bezpeka derzhavy yak zaporuka stabilnoi finansovoi bezpeky Ukrainy// Visnyk studentskoho naukovoho tovarystva DonNU imeni Vasylia Stusa// Neshko R. M., Matviichuk V. I. -Tom 2.-No.8.-2016. [Electronic resource]. — Access mode: http://jvestnik-sss.donnu.edu.ua/article/view/3914
} 
from accounts or alienation of property, other assets in favour of the state in court or the development of a debt restructuring mechanism;

- privatization of state-owned enterprises that are not strategic or priority and have suffered losses for objective reasons, and not artificially created for more than 5 years (to reduce costs from the state budget).

So, if the country has an imperfect tax system, then as a result there is a shortfall in the budget - a violation of the balance of budget security, then there will be a shortage of funds - a decrease in the level of debt security through covering the budget gap due to borrowing, there will be a reduction in gold and foreign exchange reserves - a decrease in the level of monetary and exchange rate security, which in turn will lead to sharp and uncontrollable fluctuations in the market situation - destabilization of the financial market (security).

\section{The tax policy of Ukraine in the architectonics of offshore tax evasion and fiscal security}

Tax policy is an important component of the tax security of the state. The tax policy should be based on new principles that can be defined by the new / newest tax code. The main essence of the new principles will be in:

tax amnesty for the first half of the year to provide an opportunity to transform the new tax system (to give citizens time to declare income / assets from which taxes are not paid). The taxpayer entering into the Program: voluntarily reported about the assets to the tax authority until the established date, pay the penalty, legitimizes an asset and gets immunity from criminal and civil prosecution (the protection of privacy and reputation protection). (No Declaration (conducting one-time permission by citizens of Ukraine)).

The second step would be to create trust: $100 \%$ e-administration, as part of the reform of the State fiscal service, with the change of name from «Fiscal service» to «Tax service» or «Department of revenues and fees», the elimination of the tax police (the elimination of TP will reduce the degree of administrative pressure on business) and the creation of a separate independent body «financial security Bureau». This will create a new opportunity in the fight against offenses during the application of tax legislation, increase efficiency and reduce corruption. Along with this, to conduct a personnel audit of the service with the analysis of quantitative and qualitative parameters of compliance with qualification requirements and to begin work on the formation of personnel recruitment in the «financial security Bureau» taking into account modern methods and technologies in the fight against tax offenses. 
The third step should be to reduce the tax burden. Decrease income tax (corporate) tax on withdrawn capital: payments between the payers of the cash-flow tax are not taxed and are not controlled (abolition of control of income and expenses, simplification of administration, reduction of corruption). The growth prospect is the growth of capitalization of companies, which increases the opportunities for obtaining external credit and attracting investments. Cash-flow tax is more flexible and convenient for business in times of crisis. Incentive for innovative re-equipment and renewal of fixed assets of enterprises, impetus for business development and economic recovery. State intervention in the economy will decrease.

Next step: strengthening the Institute of transfer pricing. (The TP control tool allows you to charge large companies with taxes on profits that «escaped» from Ukraine to offshore zones). Introduction of mandatory taxation of income of Ukrainian corporations received abroad, cancellation of the existing deferral of payment of this tax before the repatriation of profits; measures to reduce the motivation of companies to move profits and assets abroad;

- launch of effective international exchange of tax and financial information as a consequence of Ukraine's ratification of the Multilateral Convention (MLI). Exchange of information (automatic) is an effective tool to identify offshore schemes and undeclared assets abroad, an important incentive for their return to the country and further legalization;

- implementation of anti-abuse algorithm (GAAR, BEPS, including CFC). Changes in the Criminal code (CC) of Ukraine of the whole section VII «Crimes in the sphere of economic activity» from $199-233$ articles, fines and sanctions should be tougher and clearer.

Table 4

TAXES AT THE STATE LEVEL (Taxes on profits of legal persons) (temporarily before transfer to the tax on the withdrawn capital)

\begin{tabular}{|l|l|}
\hline \multicolumn{1}{|c|}{ Income } & \multicolumn{1}{|c|}{ Rate } \\
\hline Company income tax in the amount of 5,000,000 UAH per year & $\begin{array}{l}2-4 \% \text { (depending on } \\
\text { conditions) }\end{array}$ \\
\hline $\begin{array}{l}\text { Company income tax in the amount of 5,000,001 to 7,000,000 per } \\
\text { year }\end{array}$ & $\begin{array}{l}6-8 \% \text { (depending on } \\
\text { conditions) }\end{array}$ \\
\hline $\begin{array}{l}\text { Company income tax in the amount of 7,000,001 to 28,000,000 } \\
\text { per year }\end{array}$ & $\begin{array}{l}12-16 \% \text { (depending on } \\
\text { conditions) }\end{array}$ \\
\hline Company income tax in the amount of 28,000,001 per year & $18 \%$ \\
\hline Tax rate applied to distribution of dividends to shareholders & $5 \%$ \\
\hline
\end{tabular}


In the case of taxes for individuals and companies, the reporting year is considered to be the usual calendar year, that is, from January 1 to December 31. The deadline for submission of the tax return of individuals - April 15, and the submission of the Declaration of income tax - November 30. Taxes are paid for the previous year. Ukraine should review the agreements on avoidance of double taxation considering the provisions of the ratified Multilateral Convention (MLI) in order to balance the system of taxation of Ukrainian companies. Customs and excise duties-do not change section VI article 215 of the tax code (excisable goods and tax rates). Rental fee-do not change section IX of article 252.20. of Tax Code of Ukraine (Rental fee for use of subsoil for extraction of mineral resources), article 253.5 (Rental fee for use of subsoil for the purposes not related to mining), article 254.4 (Rental fee for use of radio frequency resource of Ukraine), article 255.5. 1 article 255.5. 2, (Rental fee for special use of water), article 256.3. 1. (Rent for special use of forest resources). In determining the amount of taxable income, so-called special and incidental expenses are deducted from total income. Special costs are related costs that have the nature of a material provision of the payer and his family in future: social insurance contributions, earmarked contributions to housing construction, the costs of vocational education and training, child support. In the group of special expenses - expenses for support of charitable, Church, scientific institutions (the total amount of such donations may not exceed $8 \%$ of the total income of the payer). Unforeseen expenses include involuntary expenses in case of treatment, disability, care for sick family members (within the established level). In addition, when determining the taxable income, age discounts (for payers over 65 years), non-taxable minimum, discounts for children are calculated from it.

The total tax burden on the payroll should not exceed $25 \%$ (including personal income tax and unified social tax paid by the employer).

\section{Special conditions for foreign investment and activities of TNCs / international / global companies}

Accordingly, in order to improve the investment climate in the country, it is necessary to attract direct and portfolio investments. They are not taxed at the «entrance», but are subject to the financial results of the activities, and the introduction of a Tax on the exported capital, the established norm will apply, but only in terms of the withdrawn capital. Regarding the activities of TNCs - they should be the same on the territory of Ukraine as foreign investments WITHOUT special conditions. 
TAX ON THE WITHDRAWN CAPITAL OF THE COUNTRY'S RESIDENTS

\begin{tabular}{|l|l|}
\hline To operations on withdrawal of capital. & $15 \%$ \\
\hline To operations equivalent to operations on withdrawal of capital. & $20 \%$ \\
\hline To the funds paid in pursuance of debt obligations to related non-residents. & $5 \%$ \\
\hline
\end{tabular}

The main objective of the tax reform is to make the tax system not entirely centralized, but on the contrary - with elements of decentralization.

Therefore, in order to decentralize the functions of the state in relation to the collection of taxes, which are one of the main sources of financing of public needs, including the needs of local communities, it is advisable to implement the following steps:

a) to give the right to local communities at the regional level through local governments of the relevant level to decide which of the local taxes provided by the Tax code, which are $100 \%$ sent to local budgets, will be collected in the territories under the jurisdiction of such communities;

b) to legislate for the local authorities the right to self-determination of the amount of benefits on payment of local taxes, in part channelled to local budgets, and definition of categories of taxpayers to which such benefits are provided;

c) to the list of controlling bodies defined by the Tax code, as such, perform the function of control over the calculation and payment of taxes, add local governments, giving them the function of control over the completeness and timeliness of payment of local taxes, which are the source of funding for the local communities;

d) to introduce a new procedure for the distribution of environmental tax, in which the lion's share of this tax will remain in the region, where the sources of pollution, which are associated with the payment of this tax, are directly located. Thus, this order shall provide the transparent mechanism of financing of programs of ecological modernization of the enterprises paying this tax or by compensation of costs of introduction of such programs, or by offset of the amounts of the costs of ecological modernization incurred by the enterprise on account of payment of its tax obligation on payment of the ecological tax;

e) to allow to distribute the tax on the income of physical persons between the local budget in the place of work and the place of vital interests of the working person (at will, for example 50/50). 


\section{Conclusions}

Analysis of the development of offshore zones, their types, features of functioning, specificity and evolution of offshore business, the experience of the world offshoring at the current stage and the place of Ukraine in the offshore world makes it possible to draw a number of conclusions.

In particular, an offshore zone is a country or separate territories of countries (Free zone, a striking example is the UAE, a resident company that can obtain a tax certificate to avoid double taxation), where significant tax benefits are established, customs and trade restrictions are partially or completely removed, accounting and audit requirements are reduced or cancelled at the state level for certain types of companies (there are two partner founders limited liability partnership 50/50\%, limited partnership $75 / 25 \%$ ), owned by foreigners.

Ukraine is a»dwarf star» in the offshore galaxy. The number of nodes associated with Ukraine (representatives, offshore companies, addresses and intermediaries) is only $0.23 \%$ of the total amount. For comparison: Russia $-3.3 \%$, Switzerland $-6.6 \%$, China $-9.2 \%$.

The simpler the scheme, the more popular it is. $40 \%$ of representatives used the simplest scheme - «Basic level», which consists of three nodes (representative, offshore, address) and two links (representative owns an offshore, representative registers the address). 468 offshore companies have been registered since 1994. The greatest boom in «offshoring» took place in 2007. In addition, Eastern Ukraine is more «offshored» than Western Ukraine.

Virgin Islands are the most popular jurisdiction for offshore registration. Their popularity increased dramatically in 2007-2011. About $10 \%$ of global GDP is offshored worldwide, but this average value covers a large heterogeneity - from a few percent of GDP in Scandinavia, to about $15 \%$ in continental Europe, and more than $50 \%$ in Russia, some Latin American countries and the Gulf countries. Accounting for offshore assets increases the level and growth of leading wealth stocks observed in tax data, but the effect value varies across countries. Offshore wealth has particularly dramatic consequences for the distribution of Russian wealth, where we estimate that about $60 \%$ of the wealth of the richest households is offshored. More broadly, offshore wealth is likely to have significant consequences for the concentration of wealth in many of the countries that are developing in the world, subsequently for the global distribution of income and wealth, which is of increasing interest.

Undoubtedly, the concept of «offshore» and the practice of this phenomenon dates back to economic relations of Ancient Greece. The 
evolution of offshore is closely associated with the evolution of money during their existence. The world enters the era of TRANSPARENCY (full transparency), there are 15 BEPS rules, automatic exchange of information between the tax countries of the world and other tools that should prevent the dominance of offshore companies in the global financial market.

To date, there are no prospects for the further development of offshore, their centres, zones, as the whole world is fighting against them. Further offshoring is a total, comprehensive offshoring, and this is practically not just impossible, but also economically unprofitable, because it will result in zero taxes and deepening of the doubtfulness of the origin of funds in the long term. It is desirable to have the best reputation, which can «dramatically» change due to the openness and speed of information dissemination, for cooperation with various international companies in the modern world. Reputation affects the conditions of doing business, for example, obtaining additional bonuses for payments, therefore to obtain competitive advantages of the business, it is necessary to provide as much true information about yourself as possible to convince your partner of your stability, reliability, social responsibility and further cooperation. Cooperation with offshore zones will lead to a deterioration of reputation, and subsequently to the reluctance or refusal of potential partners from further cooperation and slowdown of the economic life of the company, as well as offshores subconsciously cause us doubts about the legality of the funds received.

\section{References}

1. 10 Best Tax Havens in the world. [Electronic resource]. - Access mode: https: / / www.fool.com /investing / general/2016/01/03/10-best-tax-havens-in-theworld.aspx [In Russian].

2. Alstadsжter, A., Johannesen N., Zucman, G. Who owns the wealth in tax havens? Macro evidence and implications for global inequality. / / Journal of Public Economics 162 (2018). - P. 96 - 100. [Electronic resource]. - Access mode: http: / / gabriel-zucman.eu/files / AJZ2018.pdf

3. Antolohiia ofshoriv: putivnyk ukrainskyi ofshornii pavutyni. [Electronic resource]. - Access mode: https: / /voxukraine.org/longreads/panama/ index_ua.html. [In Ukrainian].

4. Apel A. Obnalichivanie y offshornyiy biznes v shemah / A. Apel, V. Gunko, Y. Sokolov. - Spb: Piter. - 2016. - p. 15. [In Russian].

5. Baula O., Sachuk. A. Osoblyvosti evoliutsii ofshornykh zon v umovakh hlobalizatsii ekonomiky. / Baula O., Sachuk. A. / / Ekonomist No.1. - 2012. No. 1. - p. 16-18.

6. Cassard M. The Role of Offshore Centers in International Finansial Intermediation / M. Cassard / / IMF Working paper. - 2014. - No. 107. - pp. 22-32. 
7. Cherep A. V. Osoblyvosti rozvytku ofshornoho biznesu v Ukraini / / Ekonomika ta derzhava. - 2014. - No. 6. - C. 21-30. [In Ukrainian].

8. Garcia-Bernardo, J., Fichtner, J., Takes, F.W. \& Heemskerk, E. M. Uncovering Offshore Financial Centers: Conduits and Sinks in the Global Corporate Ownership Network. [Electronic resource]. - Access mode: https: / / www.nature.com/articles / s41598-017-06322-9

9. Iz istorii «ofshorov» ili kakaya byila tenevaya ekonomika ranshe. [Electronic resource]. - Access mode: https://homsk.com/martin/iz-istorii-ofshorov-ili-kakayabyla-tenevaya-ekonomika-ranshe [In Russian].

10. Ishchenko V. V. Podatkova skladova finansovoi bezpeky derzhavy V. V. Ishchenko / / Visnyk ekonomiky transportu $i$ promyslovosti. - 2012. No. 37. - p.36

11. Kakie offshoryi nuzhnyi Ukraine. [Electronic resource]. - Access mode: https: / / www.epravda.com.ua/rus / columns / 2016/04/15/589562 /

12. Kose D. D. Mistse pravovoho rezhymu opodatkuvannia ofshornoi terytorii u sferi rehuliuvannia ekonomichnykh vidnosyn / D. D. Kose / / Chasopys Kyivskoho universytetu prava. - 2017. - No. 1. - pp. 18-23. [In Ukrainian].

13. Lutsenko I. S. Metodychnyi pidkhid do otsiniuvannia rivnia podatkovoi bezpeky derzhavy / I. S. Lutsenko / / Naukovyi visnyk Khersonskoho derzhavnoho universytetu. - 2015. - No. 12. - C. 160;

14. Lutsyshyn Z. O., Mekhtiiev Ye. O. Ofshorni finansovi tsentry u hlobalnomu rusi kapitaliv. / Lutsyshyn Z. O., Mekhtiiev Ye. O. / / Mizhnarodna ekonomichna polityka. - 2017. - 2 (27). - pp.62-94. [Electronic resource]. - Access mode: http://iepjournal.com/journals /27/2018_3_Lutsyshyn_Mekhtiiev.pdf

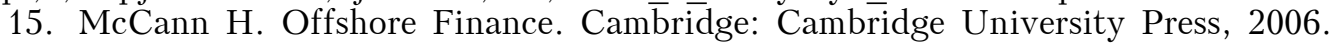
Report of the Working Groupon Offshore Centers: Financial Stability Board, 2014 [Electronic resource]. - Access mode: http://www.financialstabilityboard.org/

16. Mizhnarodni finansy: Navch. posib. / O. M. Mozghovyi, T. Ye. Obolenska, T. V. Musiiets ta in., Za zah. red. d-ra ekon. nauk, prof. O. M. Mozghovoho - K.: KNEU, 2005. - pp. 89-90. [In Ukrainian].

17. Moskalenko, N. V. Problemy, zumovleni funktsionuvanniam ofshornykh yurysdyktsii, ta shliakhy yikh rozviazannia [Tekst] / Moskalenko N. V. / / Aktualni problemy ekonomiky. - 2009. - No. 10. - pp. 117-121. [In Ukrainian].

18. Nakaz Ministerstva ekonomiky Ukrainy vid 29 zhovtnia 2013 r. No. 1277 «Pro zatverdzhennia Metodyky rozrakhunku rivnia ekonomichnoi bezpeky Ukrainy» [Electronic resource]. - Access mode: http://search.ligazakon.ua/1_doc2.nsf / link1/ME07222.html.

19. Nazvanyi stranyi, cherez kotoryie transnatsionalnyie korporatsii chasche vsego vyivodyat dengi $\mathrm{v}$ offshor. [Electronic resource]. - Access mode: https: / / news.finance.ua/ru / news / - / 407220/nazvany-strany-cherez-kotoryetransnatsionalnye-korporatsii-chashhe-vsego-vyvodyat-dengi-v-offshor

20. Neshko R. The concept of national financial security and methods of its evaluation / R. Neshko, V. Matviychuk / / Economic and Law Paradigm of Modern Society. - 2016. - P. 84-93.

21. Neshko R., Matviichuk V. Podatkova bezpeka derzhavy yak zaporuka stabilnoi finansovoi bezpeky Ukrainy / / Visnyk studentskoho naukovoho tovarystva DonNU imeni Vasylia Stusa// Neshko R. M., Matviichuk V. I. - Tom 2. - No.8. - 2016. [Electronic resource]. - Access mode: http://jvestnik-sss.donnu.edu.ua/ article/view/3914 [In Ukrainian]. 
22. «Ofshorni zony: vydy ta osoblyvosti». // Hazeta Vikna. [Electronic resource]. - Access mode: / / http://vikna.if.ua/cikavo/68688/view. [In Ukrainian].

23. «Offshoryi v mire: 7 klyuchey dlya ponimaniy» a. [Electronic resource]. Access mode: https://ru.hromadske.ua/posts/Offshory_V_Mire_7_Klyuchej_ Dlya_Ponimaniya. [In Russian].

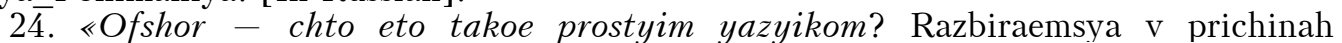
skandala» [Electronic resource]. - Access mode: https://sputnikgeorgia.ru/amp/spravka/20160406/231003155/Ofshor-chto-jeto-takoe-prostymjazykom-Razbiraemsja-v-prichinah-skandala.html [In Russian].

25. «Offshoryi: chto eto takoe prostyimi slovami? Chto takoe offshornyie zonyi primer vyivoda deneg». [Electronic resource]. - Access mode: https: / /bablolab.ru / finansy/offshory-chto-eto-takoe-prostymi-slovami.html [In Russian].

26. Petrenko L. M. Podatkova bezpeka yak skladova finansovoi bezpeky derzhavy / L. M. Petrenko / / Modeliuvannia ta informatsiini systemy v ekonomitsi: zb. Nauk. Prats; M-vo osvity i nauky Ukrainy, DVNZ «Kyiv. Nats. Ekon. Un-t im. V. Hetmana»; vidp. Red. V. K. Halitsyn. - 2012. - Vyp. 86. - p.89

27. Podik I. I. Otsiniuvannia suchasnoho stanu podatkovoi bezpeky Ukrainy / Ekonomika ta derzhava. - No. 4/2017. - p. 46. [Electronic resource]. - Access mode: http: / / www.economy.in.ua/pdf/4_2017/11.pdf [In Ukrainian].

28. Skhemy ta perspektyvy vyvodu kapitaliv do ofshornykh zon. / / Informatsiino-analitychnyi portal Ukrainskoho ahentstva finansovoho rozvytku. 2015. [Electronic resource]. - Access mode: http://www.ufin.com.ua/. [In Ukrainian].

29. Skladnist ofshornykh zon v Ukraini. [Electronic resource]. - Access mode: https: / / forum.pravda.com.ua /index.php?topic=923744.0 [In Ukrainian].

30. Swiss national bank offers a negative interest. - 2017. - P. 20. [Electronic resource]. - Access mode: https://www.snb.ch/en/mmr/reference/banks_2017/ source/banks_2017.en.pdf

31. The Global Financial Centres Index 24 September. - 2018. - P. 14-15. [Electronic resource]. - Access mode: https://www.longfinance.net/media/ documents/GFCI_24_final_Report.pdf

32. Verhun V. A. Hlobalnyi riven rehuliuvannia praktyky stvorennia i diialnosti ofshornykh zon i terytorii / Verhun V. A., Stupnytskyi O. I. / / Problemyi razvitiya oneshneekonomicheskih soyazey $i$ privlecheniya inostrannyih investitsiy: regionalnyiy aspekt : sb. nauch. Tr. / red. Yu. V. Makohon [y dr.]. - Donetsk : DNU, 2013. p. 44. [In Ukrainian].

33. Volkova Yu.A. Rozvytok ofshornykh tsentriv u systemi mizhnarodnoho biznesu / Yu.A. Volova / / Formuvannia rynkovykh vidnosyn v Ukraini. - 2013. - No.1. pp. 43-48. [In Ukrainian].

The article was received by the editorial board on 11.02.2019. 